\title{
The Creative Destruction of Copyright: Napster and the New Economics of Digital Technology
}

\author{
Raymond Shih Ray Ku†
}

To determine whether sharing music over peer-to-peer networks such as Napster should be considered copyright infringement, we must first conclude that digital works are entitled to copyright protection. This Article argues against copyright protection for digital works because the economics of digital technology undercuts prior assumptions about the efficacy of a private property regime for information, a public good. Questioning the conventional wisdom that the two interests served by copyright, creation and public dissemination, are aligned, the Article reveals that the argument for copyright is primarily an argument for protecting content distributors in a world in which middlemen are obsolete. Copyright is no longer needed to encourage distribution because consumers themselves build and fund the distribution channels for digital content. With respect to the creation of music, this Article argues that exclusive rights to reproduce and distribute copies provide little if any incentive for creation, and that digital technology makes it possible to compensate artists without control.

\section{INTRODUCTION}

That ideas should freely spread from one to another over the globe, for the moral and mutual instruction of man, and improvement of his conditions, seems to have been peculiarly and benevolently designed by nature, when she made them, like fire, expandable over all space, without lessening their density in any point, and like the air in which we breathe, move, and have our physical being, incapable of confinement or exclusive appropriation.

Thomas Jefferson ${ }^{1}$

The combination of the Internet and digital technology presents copyright law with what has been described as a digital dilemma. ${ }^{2}$ On

$\dagger$ Associate Professor of Law; Director, Institute of Law, Science \& Technology, Seton Hall University School of Law. I would like to thank David Barnes, Mark Lemley, Michael Risinger, Daniel Solove, Charles Sullivan, and the editors of The University of Chicago Law Review for their comments and insights. I would also like to thank the Seton Hall Law School faculty scholarship fund for its financial support of this project, and my research assistant Dina Kerman for her capable assistance. Special thanks to my wife Melissa for her constant support and encouragement.

1 Letter from Thomas Jefferson to Isaac McPherson, Aug 13, 1813, in Saul K. Padover, ed, The Complete Jefferson 1011, 1015 (Duell, Sloan \& Pearce 1943).

2 See Committee on Intellectual Property Rights and the Emerging Information Infrastructure, National Research Council, The Digital Dilemma: Intellectual Property in the Information Age (National Academy 2000) (describing as a "digital dilemma" the technical, legal, politi- 
one hand, digital technology makes it possible to make an unlimited number of perfect copies of music, books, or videos in digital form, and through the Internet individuals may distribute those digital works around the world at the speed of light. ${ }^{3}$ As demonstrated by Napster, the controversial peer-to-peer music-sharing network, this combination makes it possible for users to share music and other works without paying for them-thus depriving copyright holders of revenue that they might otherwise have received if individuals purchased those works in tangible form. ${ }^{5}$ On the other hand, when combined with legal sanctions, digital technology also makes it possible to control information to an unprecedented degree. ${ }^{6}$ Using encryption, trusted systems, and digital watermarking technology, distributors of digital works may not only preserve existing markets for their works, but they may also create new markets.' Digital technology therefore has "the potential to demolish a careful balancing of public good and private interest that has emerged from the evolution of U.S. intellectual property law over the past 200 years.",

As a result of the digital dilemma, we are in the midst of a great debate over the proper scope of copyright in the twenty-first century. At stake is the balance of power in the information age. On one side, content providers such as artists, the entertainment industry, and selfdescribed copyright "optimists" argue that copyright law should be extended and modified to allow copyright holders to control all distribution and use of digital information. ${ }^{.0}$ For example, Paul Goldstein

cal, economic, sociological and psychological issues relating to the advent of digital information, computer networks, and the World Wide Web). See also Information Infrastructure Task Force, Intellectual Property and the National Information Infrastructure: The Report of the Working Group on Intellectual Property Rights 178 (Sept 1995) ("White Paper"), available online at $<$ http://www.uspto.gov/web/offices/com/doc/ipnii/> (visited Dec 23, 2001) (discussing balancing the access needs of Internet users with the rights of owners to control access to their works).

3 See Part I.

4 Napster was "a program that would allow computer users to swap files with one another directly, without going through a centralized file server or middleman." Karl T. Greenfeld, Meet the Napster, Time 60 (Oct 2, 2000). For a discussion of peer-to-peer networking, see John Borland, The P2P Myth: Democracy's Traffic Jams at II 11, CNET News.com (Oct 26, 2000), available online at $<\mathrm{http}: / /$ news.cnet.com/news/0-1005-201-3248711-2.html> (visited Dec 23, 2001).

5 See Part III.A.

6 See Part I.

7 Id.

8 National Research Council, Digital Dilemma at 2 (cited in note 2).

9 Paul Goldstein, Copyright's Highway: The Law and Lore of Copyright from Gutenberg to the Celestial Jukebox 15-26 (Hill \& Wang 1994).

10 See Part II.B. Some critics have also labeled these advocates as "copyright maximalists" and opponents of expanded copyright regulations as "copyright minimalists." See, for example, Pamela Samuelson, The Copyright Grab at If 1, Wired (Jan 1996), available online at $<$ http://www.wired.com/wired/archive/4.01/white.paper_pr.html> (visited Dec 23, 2001) (criticizing the Clinton administration's proposed copyright legislation for giving too much control to copyright owners at the expense of the freedom and privacy of the general public). 
argues that copyright should be extended "into every corner where consumers derive value from literary and artistic works." According to Professor Goldstein, the next logical step in copyright's trajectory is the creation of a "celestial jukebox" in which individuals have access to an unprecedented library of music, literature, and video-on a payper-use basis, of course. ${ }^{12}$ According to the optimists, the free downloading and file sharing of music facilitated by Napster is nothing more than theft.

Critics counter that exceptions to copyright should be recognized under the fair use doctrine for certain uses of digital information. ${ }^{13}$ In response to efforts to expand copyright, the critics primarily rely upon some fundamental or overriding public interest. For example, Yochai Benkler argues that freedom of speech should limit copyright's expansion. ${ }^{14}$ Julie Cohen suggests that the First Amendment supports a right to read anonymously, ${ }^{15}$ and others argue that exceptions to copyright should be recognized for productive uses of information, including scholarship and scientific research. ${ }^{16}$ The principal question asked in the current debate is whether certain uses of copyrighted information are of sufficient social value to merit the recognition of a new exception, or to preserve an existing exception, to copyright in cyberspace."

While these critiques are important, they only respond to a subset of the problems presented by the digital dilemma. Specifically, they do not address the copyright questions presented by the recent decisions against Napster, ${ }^{18}$ MP3.com, ${ }^{19}$ and 2600 magazine, ${ }^{20}$ or consumer con-

11 Goldstein, Copyright's Highway at 236 (cited in note 9).

12 Id.

13 See Part II.C.

14 Yochai Benkler, Free as the Air to Common Use: First Amendment Constraints on Enclosure of the Public Domain, 74 NYU L Rev 354, 386-87, 393-401, 412-14 (1999) (analyzing the conflict between the interests protected by the First Amendment and those served by copyright, and critiquing the claim that copyright increases diversity of information or promotes free expression).

15 Julie Cohen, A Right to Read Anonymously: A Closer Look at "Copyright Management" in Cyberspace, 28 Conn L Rev 981, 1003-19 (1996) (arguing that the First Amendment protects the right to read anonymously because of "the close interdependence between receipt and expression of information and between reading and freedom of thought").

16 See Part II.C

17 On October 1, 2000, Harvard Law School sponsored a debate on "The Future of Intellectual Property on the Internet." One of the discussions that took place between Stanford professor Lawrence Lessig and Jack Valenti, President of the Motion Picture Association of America, nicely illustrates the arguments on both sides of this controversy. See The Future of Intellectual Property on the Internet: A Debate (Berkman Center for Internet and Society, Harvard Law School 2000), available online at <http://cyber.law.harvard.edu/futureofip/archive.asp > (visited $\operatorname{Dec} 23,2001)$.

18 A \& M Records, Inc v Napster, Inc, 114 F Supp 2d 896, 927 (N D Cal 2000) ("Napster F") (granting motion for preliminary injunction against Napster), affd in part and revd in part, 239 F3d 1004,1029 (9th Cir 2001) ("Napster II") (holding that the plaintiff established a likelihood of success on copyright claims, but the district court's preliminary injunction was overbroad). 
cerns raised in those cases over restrictions on their ability to copy works for personal and noncommercial use. The average consumer would find it difficult, if not impossible, to argue that her conduct should be protected because it is necessary for the pursuit of scholarship, or that restricting her ability to share files infringes upon her right to speak freely or invades her privacy. Yet the millions of individuals who share files through Napster, or copy music they have purchased so they can listen to it in the home, car, or office do not consider personal copying to be piracy or inconsistent with intellectual property laws. Instead, the rise of a pay-per-use world can be seen as an invasion of their liberty, an age-old criticism that was best described by British historian Thomas Macaulay when he declared that copyright was "'a tax on readers for the purpose of giving a bounty to writers." "22 Certainly some of the public's sentiments regarding copyright are self-serving, but not all of them. ${ }^{23}$ So is there a response to the claim that Napster users are stealing?

In addressing the digital dilemma and the problems presented by Napster, we are ignoring a fundamental question: Should digital works be entitled to copyright protection at all? ${ }^{24}$ By asking whether a particular use should be exempted from copyright, we assume that digital works are entitled to copyright protection in the first instance. Traditionally, the answer to the question-Is copyright needed as an incentive for the creation of intellectual works and their dissemination to the public? -was relatively straightforward. Copyright was necessary

19 UMG Recordings, Inc v MP3.COM, Inc, 92 F Supp 2d 349, 353 (S D NY 2000) (denying MP3.com's fair use defense as a matter of law).

20 Universal City Studios, Inc v Reimerdes, 111 F Supp 2d 294, 304 (S D NY 2000) (enjoining the distribution of a computer program designed to allow private copying of DVDs).

21 See Dick Kelsey, Jury Pool Survey - Napster's Chances Good at II 2, Newsbytes (Oct 10, 2000), available online at $<\mathrm{http}: / /$ www.newsbytes.com/news/00/156450.html $>$ (visited Dec 23, 2001) (reporting that " 41.5 percent of 1,000 men and women over 18 years of age believe that taking copyrighted music off the Internet should be free if it's for personal use"); Jefferson Graham, Napster Fans Angered by Deal, USA Today 1A (Nov 2, 2000) (reporting that fans accused Napster of selling out by agreeing to a licensing agreement); Office of Technology Assessment, Copyright \& Home Copying: Technology Challenges the Law, 163-65 (GPO 1989) (noting that the public seems to think it fair to leave current home taping practices unchanged).

22 Stephen Breyer, The Uneasy Case for Copyright: A Study of Copyright in Books, Photocopies, and Computer Programs, 84 Harv L Rev 281, 281 (1970), quoting T. Macaulay, Speeches on Copyright 25 (C. Gaston 1914).

23 Charles Mann, The Heavenly Jukebox, Atlantic Monthly 39, 57 (Sept 2000) (noting that user sentiment regarding music sharing is based partly upon greed); Jon Pareles, Envisaging the Industry as the Loser in Napster, NY Times E1 (Feb 14, 2001) ("Napster provides something that for many listeners is even more desirable than free tunes: access.").

24 In this respect this Article builds upon then-Professor Breyer's landmark work, in which he suggested that copyright protection for books, among other works, may not be justified because market principles would ensure a sufficient financial return for the original publisher of a work. See Breyer, 84 Harv L Rev at 291-308 (cited in note 22). 
to provide financial incentives for both creation and distribution. ${ }^{25} \mathrm{Be}-$ fore the Internet, the rights of authors, publishers, and the public were generally aligned because of one important fact: providing the public with access to content was costly. ${ }^{25}$ Regardless of whether content creators required a financial incentive to create, distributors of content required a financial incentive to make the necessary investments to distribute those works to the public. ${ }^{27}$ Who would invest the money necessary to press thousands of albums of a new recording artist or purchase printing presses, paper, and ink to publish a new novel unless there was the potential to recoup that initial investment and then some? Because of the costs of copying and distribution, the interests of creators and distributors were generally bundled together and treated as one, and the rights granted under copyright law were seen as consistent with Congress's power to "promote the progress of Science and useful Arts." ${ }^{, 23}$ While disembodied ideas may spread freely as Jefferson suggested, the books and albums conveying those ideas come at a price. But what happens in a world in which the cost of duplicating and distributing music and other creations of the mind is zero? Beyond the rhetoric, what happens to copyright if we take seriously the proposition that the Internet and digital technology are truly revolutionary?

This Article argues that cyberspace and the economics of digital technology require the unbundling of the public's interests in the creation and distribution of digital works. Once they are unbundled, the assumption that digital works are entitled to copyright protection is no longer warranted. Critics of Napster and other file-sharing technologies fear the power of the Internet to distribute digital information "virally," that is, the potential for a single digital copy of a work to be duplicated without limit and spread throughout the Internet. When creation and distribution are unbundled, however, it becomes clear that this viral nature of digital information represents a development

25 While Breyer suggested that it might still be possible for publishers to profit in a world of plastic, paper, and ink without copyright because the initial publisher always enjoys the benefit of being first to market, even he recognized that copyright might still be necessary because subsequent pirating might undermine the initial investment. See id at 300-05; Stephen Breyer, Copyright: $A$ Rejoinder, 20 UCLA L Rev 75, 80 (1972).

26 See Part IV.

27 See, for example, Jessica Litman, Digital Copyright 15 (Prometheus 2001) ("If creators can't gain some benefit from their creations, they may not bother to make new works."); Jack Valenti, Copyright \& Creativity-The Jewel in America's Trade Crown: A Call to the Congress to Protect and Preserve the Fastest Growing Economic Asset of the United States 118 (Jan 22,2001), available online at <http://www.mpaa.org/jack/2001/01_01_22b.htm> (visited Dec 23, 2001) ("Who will put up risk capital if expensive copyright works are taken without payment or permission? Who and Why?"). But see Breyer, 84 Harv L Rev at 282 (cited in note 22) ("It would be possible, however, to do without copyright.").

28 US Const Art I, $\$ 8, \mathrm{cl} 8$. 
to be embraced rather than feared, precisely because technology makes viral distribution possible at no cost to the content provider. To the extent that there are costs associated with disseminating digital content, they are borne by the users of information through the purchase of computer equipment and connections to the Internet. ${ }^{30}$ As such, the Internet and digital technology eliminate one of the principal problems created by the public good nature of information-the public's failure to internalize the cost of distributing intellectual works. ${ }^{31}$ Copyright, therefore, is no longer necessary to create property rights artificially in digital works to eliminate free riding. ${ }^{32}$

The economics of digital technology also suggests that the exclusive rights created by copyright are inconsistent with society's interest in promoting the creation of new music and making music widely available to the public. ${ }^{33}$ When the incentives for creation are examined in isolation from the incentives for distribution, the argument that copyright should limit personal and noncommercial copying of music cannot be justified, because of the existence of financial incentives for musicians to make music and the minimal role that copyright plays in creating those incentives. Moreover, in light of alternative methods for funding musicians, including statutory levies, ${ }^{34}$ denying the public access to music can no longer be justified as a necessary or desirable means for encouraging the creation of music.

Under these circumstances, the file sharing enabled by digital technology and Internet services such as Napster is not theft. Instead, it is an example of what Joseph Schumpeter described as "creative destruction." ${ }^{35}$ In his landmark work Capitalism, Socialism, and Democ-

29 See Part I.

30 See Part IV.

31 Id

32 A copyright owner's exclusive right to control the copying and distribution of her work traditionally was considered necessary to prevent members of the public from enjoying the benefits of the work without contributing to defray its costs (that is, free riding). See Part II.A.

33 With respect to copyright as a means for encouraging creation, this Article focuses on the creation of music. As discussed in Part V, the financial investment necessary to create music is minimal, and more importantly, copyright's exclusive rights to copy and distribute music play a negligible role in providing royalties to musicians. The vast majority of musicians derive their income from other sources, such as concert ticket sales. Differences in the costs of creating other works, including books, computer software, and motion pictures, and the availability of alternate sources of revenue may result in different conclusions. A detailed discussion of these differences is beyond the scope of this Article.

34 A statutory levy is a tax that could be imposed on the sale of various goods and services related to the duplication and distribution of digital works that would then be used to fund creation. As discussed in Part VI, this is the funding scheme adopted by the Audio Home Recording Act of 1992, see notes 327-30 and accompanying text, and being considered by the German government.

35 Joseph A. Schumpeter, Capitalism, Socialism, and Democracy 81-86 (Harper Perennial 1976). 
racy, Schumpeter argued that the most important form of competition keeping capitalist markets from becoming monopolistic is not competition in the ordinary sense, such as competition with respect to price, quality, and effort. ${ }^{36}$ Instead, the "fundamental impulse that sets and keeps the capitalist engine in motion" is the process of creative destruction, ${ }^{37}$ a process "that incessantly revolutionizes the economic structure [by] incessantly destroying the old one, incessantly creating a new one.",33 This is a form of competition that "strikes not at the margins of the profits and the outputs of existing firms but at their foundations and their lives. ${ }^{39}$ In this process of creative destruction, digital technology and the Internet strike at the foundation of copyright and the industries built upon copyright by eliminating the need for firms to distribute copyrighted works and for exclusive property rights to support creation.

Part I of this Article briefly describes how digital technology facilitates both the copying and dissemination of information as well as how it can be used to restrict access to information. Part II begins by discussing the first principles of copyright law, and then examines the current debate between those in favor of expanding copyright and those against it. Part III analyzes how this debate has played out in three recent cases, and the limits of fair use as a defense for private consumer copying.

The Article then asks whether copyright protection for digital works is necessary for the creation and dissemination of digital works and suggests that the economic justifications for copyright do not support exclusive rights to reproduce and distribute digital works. After analyzing why copyright was justified in the past, Part IV argues that the economics of digital technology eliminates the need for copyright as an incentive for distribution. Part V examines the role copyright currently plays in encouraging the creation of music, and whether the elimination of copyright will impact music creation. It then identifies existing sources of revenue for musicians and how free music may in fact increase revenue to artists.

If additional funding to support creation is considered necessary, Part VI proposes the Digital Recording Act. Instead of relying upon the artificial property regime created by copyright's exclusive rights to reproduce and distribute works, the proposal would fund the creation of music through taxation of computer and other electronic equipment and services that facilitate the copying of digital music, with those funds disbursed to artists based upon aggregate Internet use. 
Part VI argues that this scheme is superior to copyright because it encourages creation while avoiding the market-distorting effects of copyright's monopoly. Rather than supporting the establishment of a "celestial jukebox," the new economics of digital technology argues against efforts to alter what Thomas Jefferson described as nature's "benevolent design."

\section{The Digital DilemMa}

The characteristics of the digital technology at the root of the digital dilemma are undisputed. While digital technology can be used to facilitate and improve copying, it can also be used to restrict access to content in ways not possible with the technologies of Gutenberg's printing press.

At the heart of the digital revolution is the ability to reduce information to binary digits. Unlike traditional analog, print, or video, in which music, writings, and images respectively were captured and conveyed as physical representations of what was recorded, digital technology reproduces those same sights, sounds, and words as numbers. For example, music is digitally recorded by measuring the height of the sound wave generated by music at 44,100 times per second and recording those samples instead of physically reproducing the sound wave in the grooves of a vinyl album. Similarly, images are digitized by reducing an image to component dots (the more dots, the more accurate the image) and assigning numbers to those dots to represent color. ${ }^{42}$ Creating a sequence of digital images digitizes video. ${ }^{43}$

By reducing information to ones and zeros, digital representation revolutionizes the characteristics of content. First, digital representation frees content from the need for a tangible medium to distribute it. In the past, content could be conveyed to the public only through physical media such as film, paper, plastic, etc., and the physical media limited its distribution and copying. ${ }^{44}$ Distributing copyrighted works in the form of books, $\mathrm{CDs}$, and videos was similar to the distribution of wine. ${ }^{\text {ts }}$ In order to distribute wine to the public, one needed bottles. Even if wine was plentiful, bottles were not. In contrast, the data rep-

40 National Research Council, Digital Dilemma at 28-29 (cited in note 2). See also Information Infrastructure Task Force, White Paper at 12 (cited in note 2) ("Any two-dimensional work can be readily 'digitized'-i.e., translated into a digital code (usually a series of zeros and ones).").

41 National Research Council, Digital Dilemma at 30 (cited in note 2).

42 Id.

43 Id.

44 Id at 32-33.

45 See John Perry Barlow, The Economy of Ideas at *2, Wired (March 1994), available online at $<\mathrm{http} / /$ www.wired.com/wired/archive/2.03/economy.ideas.html $>$ (visited Dec 23, 2001) (analogizing copyright to the distribution of wine in bottles). 
resenting a recent hit song, a newborn's picture, or a scholar's work in progress no longer need to be carried in plastic or on paper. Digital information can be conveyed without the need for a bottle. ${ }^{46}$ Reduced to ones and zeros, digital information can be transmitted through the radio waves of the electromagnetic spectrum, as electrical impulses through telephone and cable wires, and as light across fiber optic networks with the information alone traveling to the recipient. ${ }^{47}$ To the extent that one desires permanently to bottle digital information for either transportation or storage, one can preserve it across media ranging from computer hard drives to CDs, floppy disks, and memory sticks.

Another revolutionary characteristic of digital reproduction is the ability to make perfect copies. An analog recording of a $\mathrm{CD}$, radio broadcast, or a photocopy of a book is not the same as the original, and subsequent copies continue to degrade. ${ }^{49}$ In contrast, digital copies are identical to the original digital master. ${ }^{50} \mathrm{~A}$ digital copy can therefore be used to produce countless subsequent digital copies, all identical to the original.

Digital technology also changes the economics of copying. Unlike the manufacturing of bottles or books, copying digital information is both inexpensive and simple. Reduced to ones and zeros, information can be copied by any home computer and stored on the hard drive or a $C D$ in minutes or seconds. ${ }^{\text {s2 }}$ Consequently, to copy an entire encyclopedia collection, one no longer needs to have the financial resources to invest in printing presses, warehouses, and employees to reproduce each volume, when the entire collection can be copied and stored so easily. ${ }^{\text {s3 }}$ Combined with the Internet, digital reproduction makes it possible for every home computer to make and distribute perfect copies worldwide at billions of bits per second. ${ }^{44}$ The only costs

46 While the Internet eliminates the need for the bottle, there may still be significant value in making old bottles. For example, while a digital book may be a less expensive, more versatile product compared to a hardbound edition, the two are not perfect substitutes. Many people may prefer the tactile sensation of paper and leather to reading on a computer screen or handheld device. Similarly, there will still be markets for compact discs in the foreseeable future given the ubiquity of compact disc players, the convenience of purchasing rather than burning discs, the reliability of the data stored on purchased CDs, and the selection of music on CDs.

47 National Research Council, Digital Dilemma at 32-33 (cited in note 2). In this respect, digital information shares the same characteristics with analog information.

48 See id at 32 .

49 See id.

so Id.

51 Id.

52 Id at 31-32.

53 See id at 32.

54 Id at 38. See also Information Infrastructure Task Force, White Paper at 12 (cited in note 2) (noting that the Internet "makes it possible for one individual, with a few key strokes, to deliver perfect copies of digitized works to scores of other individuals-or to upload a copy to a 
of becoming a global distributor (or pirate) of digital content are the price of a computer, Internet access, and electricity.

Combined, the characteristics and economics of digital reproduction eliminate some of the most important obstacles to copying. Traditionally, the investments needed to reproduce and distribute content in a physical form, the physical form itself, and the poor quality of reproductions deterred copying. ${ }^{\text {ss }}$ The size of the investment needed to make bottles and distribute those bottles limited the number of copiers. Likewise, the physical bottles made it possible to find and seize copies, and the quality of copies made them less than perfect substitutes. $^{\text {s6 }}$ These obstacles were the natural outgrowth of the way in which content was distributed and the economics associated with distribution. Digital technology is not bound by these restraints.

The digital music experience illustrates the impact of digital technology on the copying and distribution of content. A typical song can be digitally recorded and then stored as an $\mathrm{MP} 3^{57}$ file approximately three megabytes in size with CD quality sound. ${ }^{58}$ The music either can be saved as an MP3 directly by an artist or can be converted from a $\mathrm{CD}^{39}$ The music file can then be distributed quickly and easily to others over the Internet through World Wide Web pages, posted in newsgroups, shared in chat rooms, or attached to e-mail. ${ }^{\text {s. }}$ Once downloaded from the Internet, a user can save MP3s on a computer's hard drive, burn them onto a blank $\mathrm{CD}$, or save them on some other storage device.

Napster and other peer-to-peer networks facilitate the distribution of digital content by allowing individuals not only to search for

bulletin board or other service where thousands of individuals can download it or print unlimited 'hard' copies").

55 See National Research Council, Digital Dilemma at 32-33 (cited in note 2) ("For every form of digital information, every copy is as good as the original and can therefore be the source of additional perfect copies, which greatly reduces what was once a natural impediment to copyright infringement.").

56 See id at 32 (noting that the copy quality decreases with each successive generation of a "traditional form" of information).

57 "MP3" stands for MPEG 1 Layer 3. "MPEG," in turn, stands for Moving Picture Experts Group. See David A. Hepler, Comment, Dropping Slugs in the Celestial Jukebox: Congressional Enabling of Digital Music Piracy Short-Changes Copyright Holders, 37 San Diego L Rev 1165, $1174 \mathrm{n} 44$ (2000), citing What is MP3? at II 3, CNET News.com (July 22, 1999), available online at <http:/www.cnet.com/software/0-3227895-7-294826.html?st.sw.top10mp3.index_ssl.sw> (visited Dec 23, 2001).

58 Hepler, Comment, 37 San Diego L Rev at 1174 (cited in note 57). See also Preston Gralla, How the Internet Works 222-23 (Que Millennium Edition 1999).

59 Gralla, How the Internet Works at 222-23 (cited in note 58).

60 See National Research Council, Digital Dilemma at 78 (cited in note 2); Information Infrastructure Task Force, White Paper at 12 (cited in note 2) (noting that the establishment of "electronic systems makes it possible for one individual, with a few key strokes, to deliver perfect copies of digitized works to scores of other individuals"); Kiersten Conner-Sax and Ed Krol, The Whole Internet: The Next Generation 361 (O'Reilly 1999). 
MP3s on the Web, but also to search for MP3s and other files stored on other people's hard drives. ${ }^{61}$ Peer-to-peer networking dramatically expands the universe of available music. Before Napster, music and other content were only available if someone posted the content to a web page or newsgroup or attached it to an e-mail. Peer-to-peer networking streamlines the publishing process by making information residing on a user's computer hard drive directly available to other users of the network. ${ }^{62}$ Using Napster or Gnutella, an individual who has recorded a favorite $C D$ onto her computer's hard drive need only log on to the network to make those songs available to millions of others to download. $^{63}$

The ease and popularity of peer-to-peer networking is demonstrated by Napster's tremendous growth. At its height, Napster was estimated to have approximately seventy-five million registered users downloading approximately ten thousand songs per second. ${ }^{64}$ According to internal estimates, Napster was capable of growing by more than 200 percent per month without marketing. ${ }^{6 .}$

Not only has technology made it easier to copy music, but it has also dramatically reduced the costs of copying. In 2001, for less than $\$ 900$, one could purchase a home computer with a high-speed processor, forty gigabyte hard drive, and CD-RW drive capable of burning CDs. ${ }^{65}$ Blank CDs with a storage capacity of seven hundred megabytes could be purchased for approximately $\$ 0.40$ each. ${ }^{67}$ Depending upon the speed, users could obtain Internet access for free or by paying up to $\$ 40$ per month. ${ }^{6 s}$ A single CD could hold approximately twenty albums worth of music, and the hard drive could hold over one thou-

61 See $A \&$ \& Records, Inc v Napster, Inc, 114 F Supp 2d 896, 905-06 (N D Cal 2000) ("Napster I").

62 Id.

63 Napster utilizes centralized servers to maintain a directory of users currently logged in to the network and files stored on each user's computer. See Napster I, 114 F Supp 2d at 905. When a user desires to download a file from another user, Napster's servers provide the relevant contact information, and the file is then transferred between users. See id at 906-07. In contrast, Gnutella and other services do not maintain centralized servers. Searches are conducted through the individual computers that make up the network. See Borland, P2P Myth at II 13-15, CNET News.com (cited in note 4) (describing the differences between Napster and Gnutella).

64 Napster I, $114 \mathrm{~F}$ Supp 2d at 902. See also Leander Kahney, Intel Says: Think Like Napster at II 2, Wired News (Aug 24, 2000), available online at <http://www.wired.com/news/ print/0,1294,38413,00.html > (visited Dec 23,2001) (reporting that Patrick Gelsinger, an executive at Intel, considers peer-to-peer networking technology "a revolution that will change computing as we know it").

65 Napster I, 114 F Supp 2d at 902.

66 See Jim Heid, Mac Focus: Feel the Burn: Toast Does More Better, LA Times T10 (Apr 19, 2001 ) (discussing pricing history of CD burners and noting that one may be purchased for $\$ 89$ ).

67 See, for example, <http://www.officedepot.com> (visited Dec 23, 2001).

68 In 2001, individuals could access the Internet over their home telephones for free or for approximately $\$ 10$ a month. Noah Rothbaum, The Prepaid Trap, Smart Money 76 (Oct 1, 2001) (noting that NetZero was providing unlimited Internet access for $\$ 9.95$ per month). 
sand albums. ${ }^{69}$ Under these circumstances, the marginal cost for a user to download or copy an MP3 is effectively zero. ${ }^{70}$ To save that music on a $C D$, the marginal cost of copying is $\$ 0.40$ per $C D$, making the average variable cost of copying an album $\$ 0.02$ per album. ${ }^{71}$ To many involved in the copyright industry, Napster's potential for distributing music and the reduced costs of copying represent the dark side of digital technology. Unbounded by the restraints of brick-and-mortar economics, anyone with a computer and Internet access is now a potential copier and distributor of music.

Technology, however, is a double-edged sword. While digital technology facilitates the copying and distribution of digital information, it also permits greater control over the use and distribution of information. As noted by Mark Stefik, with the development of technology, "authors and publishers can have more, not less, control over their work." As Lawrence Lessig explained to the legal community, because digital technology relies upon computer code to function, computer code can be used to regulate behavior. ${ }^{73}$ For example, through the use of trusted systems, current copyright holders can use technology to control how works are accessed. Trusted systems use encryption $^{75}$ to prevent unauthorized access to digital content, and

69 These calculations are based upon the assumptions of three megabytes per song and twelve songs per album.

70 Marginal costs "include only the additional costs of producing one more unit." David W. Barnes and Lynn A. Stout, Cases and Materials on Law and Economics 349 (West 1992). For the purposes of this calculation, the cost of electricity is not included. The fact that the marginal cost for downloading music is zero is not an entirely new economic phenomenon in regards to content distribution. Both broadcast and to some degree movie theaters share similar economic characteristics because the cost of adding an additional viewer or listener is zero, or in the case of a theater, the cost of adding an additional audience member is zero until the theater is full. However, the total fixed costs of Internet distribution are significantly lower. See id (defining total fixed costs as the costs that do not vary with how much is produced).

71 Average variable cost is "the sum of all variable costs divided by output." Phillip Areeda and Donald F. Turner, Predatory Pricing and Related Practices under Section 2 of the Sherman Act, 88 Harv L Rev 697, 700 (1975).

72 Mark Stefik, Shifting the Possible: How Trusted Systems and Digital Property Rights Challenge Us to Rethink Digital Publishing, 12 Berkeley Tech L J 137, 138 (1997).

73 For a general discussion, see Lawrence Lessig, Code and Other Laws of Cyberspace (Basic 1999).

74 "A trusted system is a system that can be relied upon to follow certain rules." Stefik, 12 Berkeley Tech L J at 139 (cited in note 72). See also Mark Gimbel, Some Thoughts on the Implications of Trusted Systems for Intellectual Property Law, 50 Stan L Rev 1671, 1672 (1998) ("Nascent technologies promise to grant the owners of digital property an unprecedented degree of control over their products.").

75 Encryption is the technology used to prevent unauthorized access to computer files typically by scrambling the data with what is known as a public key. The data can then only be unscrambled with the corresponding private key. See Sabra Chartrand, A New Encryption System Would Protect a Coveted Digital Data Stream, NY Times C8 (July 3, 2000) (discussing how encryption can be used to protect digital music). 
they use rights management ${ }^{76}$ to determine what "rights" any given user has with respect to that content. ${ }^{n}$ By distributing music through a trusted system, content providers can not only charge users for every copy made, they could theoretically charge users every time a song is played, limit the locations in which a file could be used, or even program a file to expire after a certain date. ${ }^{7}$

Trusted systems already exist for the distribution of digital content on the Internet. For example, RealAudio, an alternative to MP3, relies upon trusted systems technology to distribute digital content in a format that can limit the ability of users to play, copy, or save files. Files saved in RealAudio format can only be played with a RealAudio player, and the player is programmed to determine whether any particular use is authorized. ${ }^{20}$ Specifically, RealAudio gives content providers the ability to stream audio or video files to users, preventing them from making permanent copies of the file, or to allow users to download permanent copies. ${ }^{\mathrm{st}}$

To date, the success of trusted systems obviously has been limited by the availability of free MP3s. To combat the spread of MP3s, the Recording Industry Association of America ("RIAA") has proposed the Secure Digital Music Initiative ("SDMI"). ${ }^{82}$ SDMI would require manufacturers of consumer electronics to adopt trusted systems technology if they want their devices to play commercially recorded mu-

76 Used in conjunction with a trusted system, rights management is the ability of a publisher of a work to define what rights subsequent users of her work will have to use, copy, or edit the work. Stefik, 12 Berkeley Tech L J at 140-41 (cited in note 72).

77 See id at 140 ("Digital rights fall into several natural categories. For example, transport rights include the rights to copy, transfer, or loan. Render rights include the right to play and print. Derivative work rights include the rights to extract, embed, and edit.").

78 Digital Video Express (Divx), LP, attempted this format as an alternative to DVD. If users owned a Divx-compatible machine, they could purchase a digital video for less than the price of purchasing a DVD, and would have the opportunity to view the video for forty-eight hours. Once the forty-eight hours passed, the disc would no longer work unless the user paid another fee. See Jim Millick and Bill Cruce, Cybertheater Visits Divx at II 9, available online at <http://www.cybertheater.com/News_Views/Divx/Divx.html> (visited Dec 23, 2001). This version of a DVD should not be confused with DivX, a new file format based upon MPEG-4 compression. See DivX Digest, available online at <http://www.divx-digest.com/help.html> (defining DivX). See also Tom W. Bell, Fair Use vs. Fared Use: The Impact of Automated Rights Management on Copyright's Fair Use Doctrine, 76 NC L Rev 557, 564-67 (1998) (arguing that an automated rights management system enabling providers to bill consumers for their use will improve the efficiency of licensing practices and may be more beneficial than the current copyright laws); Eric Schlacter, The Intellectual Property Renaissance in Cyberspace: Why Copyright Law Could Be Unimportant to the Internet, 12 Berkeley Tech L J 15, 38 (1997) (discussing rights management systems as alternatives to copyright).

79 See RealNetworks, Inc v Streambox, Inc, 2000 US Dist LEXIS 1889, *4-5 (W D Wash) (discussing the process by which RealAudio files are controlled).

80 Id at $* 5$.

81 Id at $* 6$.

82 See Matt Richtel and Sara Robinson, Ear Training: A Digital Music Primer, NY Times C6 (July 19, 1999). 
sic. $^{83}$ If successful, SDMI would reportedly prevent users from "ripping" CDs, burning CDs, downloading music, or copying to a portable player unless they have paid for the privilege. The motion picture industry adopted a similar approach with digital movies distributed on DVDs. Each DVD is encrypted by a copy protection system known as the Content Scramble System ("CSS"). A movie recorded on DVD may only be viewed on players and computer equipment using CSSlicensed technology, and the equipment is programmed to permit the user to play, but not copy, the movie.

Digital technology, therefore, has the power to set music free or lock it up. The great debate of the twenty-first century is over which direction we shall take. The terms of this debate, however, are not about technology. As Ithiel de Sola Pool wrote, technology "shapes the structure of the battle, but not every outcome." termine the outcome.

\section{THE COPYRIGHT DEBATE}

\section{A. Copyright First Principles}

The United States Constitution gives Congress the power " $[t] 0$ promote the Progress of Science and useful Arts, by securing for limited Times to Authors and Inventors the exclusive Right to their respective Writings and Discoveries." ${ }^{\infty}$ With regard to music, books, and movies, Congress has chosen to promote progress through the law of copyright. ${ }^{90}$ Copyright law gives authors certain exclusive rights in their works, including (as the name describes) the right to copy." As

83 Id.

84 Id.

85 See Universal City Studios, Inc v Reimerdes, 111 F Supp 2d 294, 303, 308 (S D NY 2000).

86 Id at 308.

87 See id at 304 ("Technological access control measures have the capacity to prevent fair uses of copyrighted works as well as foul. Hence, there is a potential tension between the use of such access control measures and fair use.").

88 Ithiel de Sola Pool, Technologies of Freedom 251 (Belknap 1983).

89 US Const Art I, $\$ 8, \mathrm{cl} 8$.

90 See 17 USC $\$ 102$ (1994 \& Supp 1999) (listing types of works protected by copyright).

9117 USC § 106 (1994 \& Supp 1999) provides:

[T] he owner of copyright under this title has the exclusive rights to do and to authorize any of the following: to reproduce the copyrighted work in copies or phonorecords; to prepare derivative works based upon the copyrighted works; to distribute copies or phonorecords of the copyrighted work to the public by sale or other transfer of ownership, or by rental, lease, or lending; in the case of literary, musical, dramatic, and choreographic works, pantomimes, and motion pictures and other audiovisual works, to perform the copyrighted work publicly; in the case of literary, musical, dramatic, and choreographic works, pantomimes, and pictorial, graphic, or sculptural works, including the individual images of a motion picture or other audiovisual work, to display the copyrighted work publicly; and in the case of sound recordings, to perform the copyrighted work publicly by means of digital audio transmission. 
the Constitution provides, copyright does not protect a natural right of an author in her work, although it is influenced by the fact that content is produced by the author's labor. Instead, copyright law represents a bargain between the public and the author in which the public grants the author certain exclusive rights in exchange for access to her creation. ${ }^{93}$ This access takes two forms: access to the work during the period of exclusive rights on terms generally dictated by the author or her assigns, and unfettered access to the work after those exclusive rights have expired."

This bargain is considered useful, if not necessary, because works of authorship share some of the characteristics of a "public good." Public goods are generally defined by two traits. First, once produced, they are virtually inexhaustible. This means that "it is possible at no cost for additional persons to enjoy the same unit of a public good." Second, it is difficult to prevent people from enjoying the good. Thomas Jefferson described the public goods nature of ideas when he wrote:

92 See Sony Corp of America y Universal City Studios, Inc, 464 US 417, 429 (1984):

The monopoly privileges that Congress may authorize are neither unlimited nor primarily designed to provide a special private benefit. Rather the limited grant is a means by which an important public purpose may be achieved. It is intended to motivate creative activity of authors and inventors by the provision of a special reward, and to allow the public access to the products of their genius after the limited period of exclusive control has expired.

See also Feist Publications, Inc v Rural Telephone Service Co, 499 US 340, 349 (1991) ("The primary objective of copyright is not to reward the labor of authors, but ' $[\mathrm{t}] \mathrm{l}$ promote the Progress of Science and useful Arts."'), quoting US Const Art I, § 8, cl 8; Mazer v Stein, 347 US 201, 219 (1954) (recognizing that the "economic philosophy behind the clause empowering Congress to grant patents and copyrights is the conviction that encouragement of individual effort by personal gain is the best way to advance public welfare"); United States v Paramount Pictures, Inc, 334 US 131, 158 (1948) ("The copyright law ... makes reward to the owner a secondary consideration."). See generally Alfred C. Yen, Restoring the Natural Law: Copyright as Labor and Possession, 51 Ohio St L J 517, 518-20 (1990) (discussing the rejection of an absolute property right in intellectual property under Anglo-American law and proposing an alternative interpretation of natural law).

93 See Litman, Digital Copyright at 80-86 (cited in note 27) (discussing the evolution in metaphors used to justify copyright laws and analyzing the effect of those metaphors on the public's willingness to offer content owners extensive control).

94 See Jessica Litman, The Public Domain, 39 Emory L J 965, 967-68 (1990) (describing dimensions of the public domain); Jessica Litman, Revising Copyright Law for the Information Age, 75 Or L Rev 19, 33 (1996) ("We want members of the public to be able to learn from [artists' works]: to extract facts and ideas from them, to make them their own, and to be able to build on them.").

95 Harold Demsetz, The Private Production of Public Goods, 13 J L \& Econ 293, 295 (1970). See Ronald V. Bettig, Copyrighting Culture: The Political Economy of Intellectual Property 79-80 (Westview 1996) (defining public goods as those that allow joint, nonrival consumption by all potential consumers); William W. Fisher III, Reconstructing the Fair Use Doctrine, 101 Harv L Rev 1659, 1700 (1988) (stating that the problem with works of intellect is that they are public goods that "can be used and enjoyed by unlimited persons without being 'used up"'). 
If nature has made any one thing less susceptible than all others of exclusive property, it is the action of the thinking power called an idea, which an individual may exclusively possess as long as he keeps it to himself; but the moment it is divulged, it forces itself into the possession of everyone, and the receiver cannot dispossess himself of it. Its peculiar character, too, is that no one possesses the less, because every other possesses the whole of it. He who receives an idea from me, receives instruction himself without lessening mine; as he who lights his taper at mine, receives light without darkening me.

At first glance, these traits appear positive. However, they can also be cause for concern when one recognizes the potential for "free riding." the likelihood that some people will enjoy the benefits of the good without internalizing the costs of its production. ${ }^{98}$ If the funding of public goods is left to the private market, free riding may lead to the underproduction of the good. ${ }^{99}$ In other words, if enough people decide that they can enjoy the benefits of a lighthouse without paying for its costs, soon there will be no lighthouse.

Astute readers will note that, while the preceding may describe ideas, songs, or poetry, it does not precisely describe CDs, books, or sculptures. While ideas may be non-exclusive, I can certainly keep people from reading my book or listening to my $C D$. As such, the $C D$ is a private good. ${ }^{100}$ Nonetheless, we have traditionally protected not only the song, but the song embodied in a $C D$ as well. The justifications for this protection are the obvious public benefits of embodying works of authorship in a tangible medium and the need to protect against the copying that threatens the publication and distribution of works. While a song or story may spread by word of mouth, fixing those works in tangible form facilitates the dissemination of those works to larger portions of the public while preserving the artist's original expression. However, once a work is distributed, subsequent copiers may be able to distribute the work without incurring costs or bearing risks equal to those borne by the initial publisher. If competi-

\footnotetext{
96 Letter from Jefferson to McPherson at 1015 (cited in note 1).

97 See generally Edwin Mansfield, Principles of Microeconomics 70, 74-75 (Norton 1974) (discussing the concept of free riding).

98 See Wendy J. Gordon, Fair Use as Market Failure: A Structural and Economic Analysis of the Betamax Case and Its Predecessors, 82 Colum L Rev 1600, 1611 (1982) (stating that one characteristic of a public good is that it is difficult to prevent persons who have not paid for a public good from using that good).

99 See id.

100 See Bettig, Copyrighting Culture at 80 (cited in note 95) (discussing the distinction between public goods, whose consumption is nonrivalrous, and private goods, whose use may be excluded from others).
} 
tion from copiers drives the price of a work down to the marginal costs of the copier or the original publisher, it threatens the incentives to distribute the work in the first place. ${ }^{101}$ If publishers have no incentive to publish new works, the public's access to or ability to enjoy those works will be significantly reduced. In other words, even though a $C D$ or book is a private good, copying still threatens the market for such goods.

Copyright, therefore, is designed not only to protect the author, but also to protect the incentives of the publisher. This is accomplished by granting authors legally enforceable rights in their works similar to property rights in tangible property, which can be used to control copying, distribution, and other uses of those works. The author assigns or licenses these rights to the publisher to protect the publisher's interests as well. Law, therefore, makes it possible to have a private market for works of authorship by artificially rendering those works scarce and exclusive.

\section{B. The Case for Expanding Copyright}

According to self-proclaimed copyright optimist Paul Goldstein:

The digital future is the next, and perhaps ultimate, phase in copyright's long trajectory, perfecting the law's early aim of connecting authors to their audiences, free from interference by political sovereigns or the will of patrons. The main challenge will be to keep this trajectory ... true to copyright's historic logic that the best prescription for connecting authors to their audiences is to extend rights into every corner where consumers derive value from literary and artistic works.

The optimists, therefore, claim that law should prevent digital technology from being used for uncompensated copying and should recognize authors' rights to use technology to lock up digital content. Copyright optimists often use the rhetoric of protecting the moral and natural rights of authors to reap what they have sown, ${ }^{103}$ but given the Constitution's utilitarian slant, their principal argument is that copyright should be extended because the financial incentives it creates in-

101 See William M. Landes and Richard A. Posner, An Economic Analysis of Copyright Law, 18 J Legal Stud 325, 326 (1989) (stating that copyright protection trades off the costs of limiting access to a work and the benefits of providing incentives to create the work in the first place); Lessig, Code and Other Laws at 133 (cited in note 73).

102 Goldstein, Copyright's Highway at 236 (cited in note 9).

103 Id at 11 ("Bubbling beneath all of them, including copyright, is the intuition that people should be able to hold on to the value of what they create, to reap what they have sown."); Testimony of Lars Ulrich, Metallica band member, before the Senate Committee on the Judiciary II 4 (July 11,2000), available online at <http://judiciary.senate.gov/7112000_lu.htm> (visited Dec 23,2001 ) (arguing that musicians should not be forced to work for free). 
crease the public good. ${ }^{104}$ The logic of their argument is powerful in its simplicity-more copyright protection produces more incentives for creation. So "if the work has commercial value, copyright's aim is to put that value in the copyright owner's pocket."

The arguments of the copyright optimists provide the foundation for what Yochai Benkler describes as the "enclosure movement," what Pamela Samuelson calls the "copyright grab." Through law and technology, copyright optimists are attempting to control not just arguably new uses of information, as represented by MP3s, but also uses of information that have historically been considered free under copyright's fair use doctrine. ${ }^{108}$ This latter category includes such uses as recording a favorite television show, copying a newspaper article to share with people at work, or copying favorite songs into a new mix to share with a friend. ${ }^{109}$ With the help of the very same digital technology that they have demonized, copyright optimists see the potential to "reverse the losses they see copyright owners suffering today when people make copies of films and sound recordings: by charging subscribers electronically for each use of the prerecorded works" through a digital "celestial jukebox.",10

To the copyright optimist, previously recognized exceptions to copyright infringement for personal, educational, and scholarly copying were grudgingly accepted because they represented instances of market failure. In other words, the uses of information that we cur-

104 Goldstein, Copyright's Highway at 11 (cited in note 9). See also Trotter Hardy, Property (and Copyright) in Cyberspace, 1996 U Chi Legal F 217, 219-229 (explaining how incentives to produce informational works can be analyzed and arranged and how such a taxonomy explains the pressures on Congress to expand copyright rights).

105 Goldstein, Copyright's Highway at 7 (cited in note 9).

106 Benkler, 74 NYU L Rev at 354-55 (cited in note 14) ("We are in the midst of an enclosure movement in our information environment. In other words, our society is making a series of decisions that will subject more of the ways in which each of us uses information to someone else's exclusive control.").

107 Samuelson, The Copyright Grab at $\mathbb{1}$ 1, Wired (cited in note 10) (arguing that the Clinton administration proposed "a wholesale giveaway to its supporters in the copyright industry").

108 See id (noting the maximalist agenda to end fair use rights). The fair use doctrine represents an historic exception to copyright liability for certain uses that fit the literal definition of copyright infringement. See Sony Corp of America $v$ Universal City Studios, Inc, 464 US 417, 447 n 29 (1984) ("The Copyright Act of 1909, 35 Stat. 1075, did not have a 'fair use' provision. Although that Act's compendium of exclusive rights 'to print, reprint, publish, copy, and vend the copyrighted work' was broad enough to encompass virtually all potential interactions with a copyrighted work, the statute was never so construed. The courts simply refused to read the statute literally in every situation."). Congress codified the doctrine in 17 USC § 107 (1994 \& Supp 1999).

109 See Sony Corp, 464 US at 456 (holding that home videotaping is fair use); id at 481-82 (Blackmun dissenting) (noting that sharing a news clipping would not be considered copyright infringement).

110 Goldstein, Copyright's Highway at 30 (cited in note 9). See also Bell, 76 NC L Rev at 579-84 (cited in note 78) (arguing for a quasi-compulsory licensing scheme).

111 See generally Gordon, 82 Colum L Rev at 1614-27 (cited in note 98). 
rently consider fair use were only tolerated because of the high transaction costs associated with negotiating, monitoring, and controlling such uses. ${ }^{12}$ According to Wendy Gordon, whose seminal work forms the foundation for this argument, exceptions to copyright should only be recognized when "the possibility of consensual bargaining has broken down in some way."

Building upon Professor Gordon's work, others argue that the fair use doctrine should be significantly narrowed because digital technology improves a copyright owner's ability to commodify intellectual property, making it more like tangible property, and reduces the transaction costs associated with bargaining and enforcement. ${ }^{114}$ For example, Tom Bell and Trotter Hardy argue that the Internet, online contracts, and technological measures designed to control access to copyrighted works reduce transaction costs, thus eliminating most instances of market failure. ${ }^{115}$ According to Professor Bell, trusted systems "radically reduce[ ] the transaction costs of licensing access to copyrighted works," and "[i]nsofar as it responds to market failure, therefore, fair use should have a much reduced scope."116 The reduction in transaction costs will benefit the public by increasing the value of copyrighted works, thus encouraging greater production and improving distribution. ${ }^{117}$ Similarly, Professor Hardy argues that because transaction costs in cyberspace "appear to be falling quite rapidly," a private property regime for information works in cyberspace would best promote the development and usefulness of cyberspace by minimizing the inefficiencies of liability rules and group bargaining costs. $^{118}$ As Professor Cohen notes, for these cyber-economists, "[d]igital technology enables the complete determination of property rights and facilitates their exchange in relatively frictionless Coasean

112 Id at 1614-15.

113 Id at 1615.

114 See, for example, Bell, 76 NC L Rev at 579-80 (cited in note 78) (arguing that "automated rights management" will sharply lower transaction costs for regulating the use of copyrighted materials); Hardy, 1996 U Chi Legal F at 236 (cited in note 104) (arguing that a principal characteristic of property rules-that we rely on them in situations of low transaction costsapplies to cyberspace, because cyberspace lowers the cost of communicating); Goldstein, Copyright's Highway at 224 (cited in note 9) ("The capacity of the celestial jukebox to post a charge for access, and to shut off service if a subscriber does not pay his bills, should substantially reduce the specter of transaction costs. As these costs dissolve, so, too, should the perceived need for safety valves such as fair use."). But see Robert P. Merges, The End of Friction?: Property Rights and Contract in the "Newtonian World of On-line Commerce", 12 Berkeley Tech L J 115, 115 (1997) ("Arguing ... that transaction costs are negligible in the on-line environment is an oversimplification.").

115 Bell, 76 NC L Rev at 580 (cited in note 78); Hardy, 1996 U Chi Legal F at 236-42 (cited in note 104).

116 Bell, 76 NC L Rev at 583-84 (cited in note 78).

117 See id at 589.

118 Hardy, 1996 U Chi Legal F at 259-60 (cited in note 104). 
markets not just because it should, but because it must."119 As noted by Ronald Bettig, this reflects the fact that neoclassical economists begin with the "value based judgment that private property is necessary to approach anything resembling economic efficiency in information markets." ${ }^{120}$

To date, the copyright optimists' digital agenda has found support in all three branches of government. Through its "White Paper," the Clinton administration championed the cause of copyright owners, ${ }^{121}$ and Congress enacted those proposals into law when it passed the Digital Millennium Copyright Act ("DMCA"). ${ }^{12}$ Congress concluded that even temporary electronic files are copies subject to copyright law; ${ }^{123}$ made it illegal to distribute or use any technology designed to circumvent technological measures protecting intellectual property regardless of whether the circumvention was for purposes of fair use; and made Internet service providers responsible for contributory infringement if they fail to remove or block allegedly infringing material on their networks.

Courts, like the President and Congress, have generally sided with the optimists, despite the judicially created fair use doctrine. ${ }^{126}$ In rejecting a fair use defense in the MP3.COM decision, Judge Rakoff went so far as to say that "[t]he complex marvels of cyberspatial communication may create difficult legal issues; but not in this case." Some courts and state legislatures have recognized a copyright

119 Julie E. Cohen, Lochner in Cyberspace: The New Economic Orthodoxy of "Rights Management", 97 Mich L Rev 462, 561 (1998). As Professor Cohen notes, one of the problems of the neoclassical economic approach underlying the enclosure movement is that it assumes an "equivalency between private wealth and social gain." Id at 560 . This assumption is particularly inappropriate given that copyright's goal is not to maximize wealth, but to maximize the number of works created and available to the public.

120 Bettig, Copyrighting Culture at 106 (cited in note 95).

121 See generally Information Infrastructure Task Force, White Paper at 178 (cited in note 2) (explaining the Clinton Administration's positions on intellectual property and the Internet).

122 Pub L No 105-304, 112 Stat 2860 (1998), codified as amended in various sections of 17 USC (Supp 1999).

123 See 17 USC $\$ 101$ (Supp 1999) (defining "copies" as "any method now known or later developed, and from which the work can be perceived, reproduced, or otherwise communicated, either directly or with the aid of a machine or device"). See also No Electronic Theft Act of 1997, Pub L No 105-147, 111 Stat 2678, codified at 18 USC $\$ \$ 2319-20$ (Supp 1999) (amending 17 USC $\S 506$ to clarify that reproduction and distribution include electronic means); US Department of Justice, Criminal Division, Computer Crime and Intellectual Property Section, The No Electronic Theft ("NET") Act: Summary of Changes to the Criminal Copyright and Trademark Laws (Feb 18, 1998), available online at <http://www.usdoj.gov/criminal/cybercrime/netsum.htm> (visited Dec 23, 2001).

124 See 17 USC $\$ \S 1201-05$ (Supp 1999).

125 See 17 USC $\$ 512$ (Supp 1999).

126 See Part III.

127 UMG Recordings, Inc v MP3.COM, 92 F Supp 2d 349, 350 (S D NY 2000). 
owner's ability to control the use of his works through "one-click" or "shrink-wrap" licensing agreements."

\section{The Fair Use Response}

With some exceptions, ${ }^{129}$ critics of the "copyright grab," who have been labeled copyright pessimists, do not challenge the application of existing copyright law to digital works. Instead, they are disturbed by efforts to expand copyright, especially in cases in which that expansion comes at the expense of other overriding societal interests. ${ }^{130}$ For example, Yochai Benkler argues that copyright's expansion should be limited by the freedom of speech guaranteed by the First Amendment. ${ }^{131}$ According to Professor Benkler, the DMCA and other aspects of the optimists' agenda are suspect because they regulate the public's ability to engage in expression. ${ }^{132}$ Julie Cohen argues that Congress and the courts should recognize a right to read anonymously as a corollary to the right to speak. ${ }^{133}$ According to Professor Cohen, the moni-

128 See ProCD, Inc v Zeidenberg, 86 F3d 1447,1455 (7th Cir 1996) (enforcing shrinkwrap licensing terms); National Conference of Commissioners on Uniform State Laws, Uniform Computer Information Transaction Act ("UCITA") I 2, available online at $<$ http://www.ucitaonline.com> (visited Jan 19, 2002) (proposing uniform rules to recognize the validity of mass market licenses for intellectual property); Md Comm Code Ann \$\$ 22-101 et seq (2000) (adopting UCITA); Va Code Ann $\$ \$ 59.1-501.1$ et seq (Michie 2001) (same). But see Kloceck v Gateway, Inc, 104 F Supp 2d 1332, 1341 (D Kan 2000) (refusing to enforce a shrinkwrap license because there was no acceptance of the license according to Kansas or Missouri contract law).

129 See Litman, Digital Copyright at 180 (cited in note 27) (raising concerns about the application of copyright to "everyone, everywhere"); Niva Elkin-Koren, Cyberlaw and Social Change: A Democratic Approach to Copyright Law in Cyberspace, 14 Cardozo Arts \& Enter L J 215, 27183 (1996) (raising concerns about the application of copyright to private use of digital works). See also Breyer, 84 Harv L Rev at 321 (cited in note 22) (arguing that the case for copyright protection of certain books is weak); Glynn S. Lunney, Jr., Reexamining Copyright's Incentive-Access Paradigm, 49 Vand L Rev 483, 487-88 (1996) (arguing that copyright protection should be limited to the extent that it creates greater incentives to invest in intellectual property than other goods).

130 See Ruth Okediji, Givers, Takers, and Other Kinds of Users: A Fair Use Doctrine for Cyberspace, 53 Fla L Rev 107, 117 (2001) (arguing for the retention of fair use standards because "copyright envisions use by members of the public"); Pamela Samuelson, Intellectual Property and the Digital Economy: Why the Anti-Circumvention Regulations Need to Be Revised, 14 Berkeley Tech L J 519, 522-24 (1999) (arguing that the DMCA's anticircumvention provisions did not adequately consider the interests of Silicon Valley); Benkler, 74 NYU L Rev at 446 (cited in note 14); Elkin-Koren, 14 Cardozo Arts \& Enter L J at 224 (cited in note 129) (noting the importance of social dialogue); David Lange, Copyright and the Constitution in the Age of Intellectual Property, 1 J Intel Prop L 119, 123 (1993) (arguing for the need for individuals to engage in "creative play").

131 Benkler, 74 NYU L Rev at 446 (cited in note 14). See also Melville B. Nimmer, Does Copyright Abridge the First Amendment Guarantees of Free Speech and the Press?, 17 UCLA L Rev 1180, 1200-04 (1970) (discussing the tension between copyright and the First Amendment and concluding that the First Amendment does not justify "the expropriation of authorship").

132 Benkler, 74 NYU L Rev at 445-46 (cited in note 14).

133 Cohen, 28 Conn L Rev at 1003-19 (cited in note 15). 
toring of individual behavior through copyright management systems may threaten self-expression by deterring individuals from reading controversial works.

Similarly, Neil Netanel argues that instead of a market-based approach, copyright should be interpreted under a democratic paradigm that recognizes the need to maintain copyright as a means of supporting a "system of self-reliant authorship, diversity, and the dissemination of information" while imposing limits consistent with copyright's democracy-enhancing function. ${ }^{135}$ Still others, including Pamela Samuelson and Jessica Litman, insist on preserving existing fair use exceptions and importing them into the digital context. ${ }^{136}$ According to Professor Litman, preserving existing fair use exceptions is consistent with the public's expectations and understanding of its bargain with copyright owners.

In many respects, these critiques are consistent with traditional efforts to define fair use as including productive or socially valuable uses. ${ }^{138}$ As Judge Leval has suggested, "In analyzing a fair use defense, it is not sufficient simply to conclude whether or not justification exists. The question remains how powerful, or persuasive, is the justification because the court must weigh the strength of the secondary user's justification against factors favoring the copyright owner." Robert Merges notes, focusing on competing values is logical: "Since markets are possible and feasible between all parties in a digital environment, the relevant policy questions will center on when it makes sense to do an 'end run' around the market."140

134 Id at 1007-10.

135 Neil Weinstock Netanel, Copyright and Democratic Civil Society, 106 Yale L J 283, 339, 362-63 (1996).

136 See Samuelson, 14 Berkeley Tech L J at 539 (cited in note 130) (arguing against the extension of copyright to such uses or their digital equivalents unless it is necessary to protect digital markets); Elkin-Koren, 14 Cardozo Arts \& Enter L J at 273, 277 (cited in note 129) (arguing that users must be allowed "to do the same things they are able to do in a non-digitized environment"); Jessica Litman, The Exclusive Right to Read, 13 Cardozo Arts \& Enter L J 29, 40 (1994) (arguing that an individual's ordinary reading, viewing or listening to an authorized copy of work does not invade the copyright owner's rights); Diane Leenheer Zimmerman, Copyright in Cyberspace: Don't Throw Out the Public Interest with the Bath Water, 1994 Ann Surv Am L 403, 405 (arguing for maintaining "some approximation of our current cheap and simple access to copyrighted works for research, scholarship and pleasure").

137 Litman, 13 Cardozo Arts \& Enter L J at 40 (cited in note 136).

138 See Pierre N. Leval, Toward a Fair Use Standard, 103 Harv L Rev 1105, 1111 (1990) ("The use must be productive and must employ the quoted matter in a different manner or for a different purpose from the original."). See also Okediji, 53 Fla L Rev at 174 (cited in note 130) (arguing that fair use in cyberspace maintains the requirement of productivity).

139 Leval, 103 Harv L Rev at 1111 (cited in note 138).

140 Merges, The End of Friction at 134 (cited in note 114). 
More recently, Professor Litman, who has argued vigorously in defense of a vibrant public domain ${ }^{141}$ has suggested that copyright's expansion requires a renegotiation of copyright's quid pro quo. ${ }^{142} \mathrm{Em}$ phasizing the classic metaphor of copyright as a bargain between the public and copyright holders and the fact that copyright holders have never been entitled to control all uses of their works, she argues that copyright's current expansion has myopically focused only on the copyright holder's side of the bargain. ${ }^{143}$ What of the public's interest? If copyright is to expand, Professor Litman argues, that expansion should reflect what the public considers to be legitimate uses of works of authorship. ${ }^{144}$ As such, she suggests that we "stop defining copyright in terms of reproduction" and focus instead on commercial exploitation. ${ }^{145}$

While I generally agree with these critiques and believe that they contribute greatly to our understanding of the relationship between copyright and other important societal interests, the circumstances they address are limited. As discussed below, attempting to identify compelling or overriding public interests to justify private copying of digital music is too great a stretch. Ultimately, copyright optimists are not arguing for a right absolutely to deny the public access to their works or to enclose the public domain permanently; it is not in their financial interests to do either. ${ }^{146}$ Instead, they simply want users to pay them for accessing those works. Under these circumstances, it is difficult to refute Professor Gordon's argument that "to propose that fair use be used whenever the 'social value ... outweighs any detriment to the artist[]' would be to propose depriving copyright owners of their

141 See Litman, 39 Emory L J at 968 (cited in note 94) (arguing that the public domain is the "device that permits the rest of the system to work by leaving the raw material of authorship available for authors to use").

142 See Litman, Digital Copyright at 174-86 (cited in note 27) (proposing that copyright law be reformulated to better incorporate the public's understanding of the copyright bargain by asking and addressing what the public wants or deserves).

143 Id at 174.

144 See id at 180 (arguing that because the public appears to believe that the copyright law incorporates a distinction between commercial and noncommercial behavior, lawmakers should think about copyright infringement in terms of what effect a user's actions have on the copyright holder's opportunities for commercial exploitation).

$145 \mathrm{Id}$.

146 See Testimony of Fred Ehrlich, President of New Technology and Business Development for Sony Music Entertainment, Inc, before the Senate Committee on the Judiciary If 16 (July 11, 2000), available online at <http://. udiciary.senate.gov/7112000_fe.htm > (visited Dec 23, 2001) (describing the recording industry's plans to enter the digital market); Valenti, Copyright \& Creativity at $\mathbb{1 4}$ (cited in note 27) ("Movie companies would be fiscally mad to want to put their films in a vault, unseen by customers."). Ironically, copyright law already gives copyright owners the right to keep a work from being published. See Harper \& Row Publishers $v$ Nation Enterprises, 471 US 539, 554-55 (1985) (recognizing an author's right to choose when first to publish). 
right in the property precisely when they encounter those users who could afford to pay for it." ${ }^{\text {,47 }}$ The wisdom of this end run around copyright can also be questioned when one takes into account that "the Framers intended copyright itself to be the engine of free expression. By establishing a marketable right to the use of one's expression, copyright supplies the economic incentive to create and disseminate ideas., ${ }^{148}$

Likewise, while I agree with Professor Litman's ultimate conclusion that we should eliminate the right of reproduction and focus intellectual property law on commercial exploitation, her solution is a political one. What happens when Congress, as it did with the DMCA, decides to give copyright owners a bigger slice of the pie $?^{149}$ As Litman demonstrates so well, throughout most of copyright's history, the legislative process has been dominated, if not captured, by the copyright industry. ${ }^{130}$ If we adopt Litman's framework, are we left only with the argument that copyright's terms are not in the public interest? ${ }^{\text {sit }}$

As presented, the copyright debate appears to be a zero-sum game. Encouraging creativity comes at the expense of public access. Similarly, allowing uncompensated access to works reduces the incentive to create future works. This is what Professor Lunney describes as the incentive-access paradox. ${ }^{152}$ The critics of the enclosure movement argue that the tradeoff between access and incentives is acceptable because the value of the particular use to society outweighs any loss of creation. As Part III of this Article demonstrates, when the use is or-

147 Gordon, 82 Colum L Rev at 1615 (cited in note 98), quoting Note, Parody and Copyright Infringement, 56 Colum L Rev 585, 595 (1956).

148 Harper \& Row, 471 US at 558. See also Eldred v Reno, 239 F3d 372, 380 (DC Cir 2001) (rejecting a First Amendment challenge to the Copyright Term Extension Act). See also Gordon, 82 Colum L Rev at 1612 (cited in note 98) ("A democratic society demands decentralized and diverse creation in the intellectual spheres; freedom from state control is essential lest freedom of expression be curtailed by governmental reprisal."); Netanel, 106 Yale L J at 288 (cited in note 135) (arguing that copyright serves democracy by funding an independent creative sector).

149 See Jane C. Ginsburg, Copyright and Control over New Technologies of Dissemination, 101 Colum L Rev 1613, 1615 (2001) (suggesting that the DMCA "may in fact have enhanced the ability of copyright owners to wield electronic protective measures to control new kinds of exploitation of their works").

150 See Litman, Digital Copyright at 22-32 (cited in note 27) (describing how the copyright industry has successfully lobbied for greater and greater copyright protection).

151 See Robert P. Merges and Glenn H. Reynolds, The Proper Scope of the Copyright and Patent Power, 37 Harv J on Legis 45, 65 (2000) (arguing that laws granting copyright term extensions should be considered unconstitutional because they represents "special-interest graft").

152 Lunney, 49 Vand L Rev at 557-58 (cited in note 129):

If we limit a work's protection to ensure its dissemination, we necessarily reduce the incentive to create such work and decrease the chance that the work would have been created in the first place. If we increase a work's protection to increase the chance of its creation, we necessarily increase the price the author will charge for the work and thereby restrict access to the work if and when it is created. 
dinary consumer use, courts are reluctant to conclude that access outweighs copyright's incentives scheme. Furthermore, as discussed in Parts IV and V, the current debate is misleading because digital technology makes it possible to resolve the incentive-access paradox, and to provide the public with access to works even for ordinary use, without diminishing the incentives for creation and dissemination.

\section{The Litigation}

Three recent decisions involving Napster, MP3.com, and 2600 magazine illustrate the current debate between copyright optimists and pessimists and the limits of that debate in helping us to understand the impact of digital technology. Without questioning copyright's assumptions, these cases attempt to import the existing fair use doctrine into the digital context. In each case, the need to preserve copyright's incentive scheme is considered paramount.

\section{A. A\& M Records, Inc v Napster, Inc ("Napster I") ${ }^{133}$}

Frustrated by the difficulty of finding MP3 files on traditional Internet servers, a college student named Shawn Fanning created Napster. ${ }^{254}$ By downloading free software, a user could log on to Napster and share music files with other users who were also on the network. ${ }^{1.5}$ Known as peer-to-peer networking, Napster enabled users to search for music on the hard drives of other users instead of searching for music available on World Wide Web pages. ${ }^{156}$ In effect, Napster made any digital home recording of music available to its members. Because the vast majority of music available on Napster was copyrighted, the recording industry brought suit for, among other things, contributory and vicarious copyright infringement. ${ }^{177}$ Napster countered that its users' "file sharing" should be considered fair use. ${ }^{155}$

In addressing these questions, the district court concluded that the recording companies established a prima facie case of direct copyright infringement by Napster's users. According to the court, "virtually all Napster users engage in the unauthorized downloading or up-

153114 F Supp 2d 896, 927 (N D Cal 2000), affd in part and revd in part, 239 F3d 1004, 1029 (9th Cir 2001).

154 Napster I, 114 F Supp 2d at 901-02. See generally Testimony of Shawn Fanning, founder of Napster, Inc, before the Senate Committee on the Judiciary III 6-12 (Oct 9, 2000), available online at <http://judiciary.senate.gov/1092000_sf htm> (visited Dec 23, 2001).

155 See Napster I, 114 F Supp 2d at 905-07 (describing the Napster technology).

156 See id at 902.

157 Id at 900 .

158 Id at 900-01. 
loading of copyrighted music." 159 The court then turned to analyzing the four factors of the fair use doctrine set forth by the Copyright Act:

(1) the purpose and character of the using, including whether such use is of a commercial nature or is for nonprofit educational purposes;

(2) the nature of the copyrighted work;

(3) the amount and substantiality of the portion used in relation to the copyrighted work as a whole; and

(4) the effect of the use upon the potential market for or value of the copyrighted work.

Because music is creative in nature, and users could download entire songs, the second and third factors weighed against fair use. ${ }^{161} \mathrm{Ac}-$ cording to the court, the purpose and character of the use also weighed against a finding of fair use. Napster's users were not using the copyrighted works in a way that transformed the copyrighted materials. ${ }^{162}$ Users were not attempting to use the songs for parody or for research, but were merely copying and listening to the music. As such, there could be no claim that the use was justified by some overriding governmental interest like the advancement of scientific or medical research. ${ }^{163}$

As to whether the use was commercial, the court concluded that while the use was not "paradigmatic commercial activity," it could not be considered personal use "in the traditional sense." "164 According to the court, the "vast scale" of file sharing facilitated by Napster could not be considered private use. ${ }^{165}$ Moreover, while the activity was not for profit, it was certainly economic in nature. The fact that "Napster users get for free something they would ordinarily have to buy suggests that they reap economic advantages from Napster use."166

Similarly, the court found that the effect of the use upon the value of the work and potential markets for the work weighed against finding that Napster use constituted fair use. According to the court, Nap-

159 Id at 911.

160 See id at 912, quoting 17 USC $\$ 107$ (Supp 1999).

161 See Napster I, 114 F Supp 2d at 913.

162 See id at $912-13$.

163 See id at 913-14. See also Williams \& Wilkins Co v United States, 487 F2d 1345, 1354 (Ct Cl 1973) (concluding that the prevention of private photocopying of scientific journals would threaten the advancement and dissemination of scientific and medical research), affd, 420 US 376 (1975) (per curiam).

164 Napster I, 114 F Supp 2d at 912.

165 Id.

166 Id. 
ster use harmed the market for copyrighted music by reducing $C D$ sales among college students and by raising barriers to entry in the market for digital downloading. ${ }^{167}$ The recording companies presented evidence of a decline in $C D$ sales at highly wired college campuses and campuses that subsequently banned Napster use. ${ }^{169}$ In the threeyear period between 1997 and 2000, the recording companies' study indicated that while $\mathrm{CD}$ sales nationwide had risen by 18 percent, sales near these college campuses dropped by $12-13$ percent. ${ }^{169}$ The inference, of course, was that the decline in sales resulted from MP3 downloads replacing CD purchases. With respect to the downloading market, the court accepted the recording industry's common-sense argument that the availability of free downloading reduced the market for competing commercial downloading, and that this downloading deprived copyright owners of royalties for downloading even if it enhanced $\mathrm{CD}$ sales.

In rejecting Napster's fair use defense, the court distinguished the Supreme Court's decision in Sony Corp of America $v$ Universal City Studios, Inc, in which the Court concluded that the home taping of copyrighted television programs was fair use. ${ }^{1 / 2}$ Unlike home VCR usage, in which users were initially invited to view the television broadcast for free, Napster users obtained permanent copies of songs that they would otherwise have had to purchase. ${ }^{173}$ Similarly, according to the court, the majority of VCR users merely enjoyed the tapes at home. In contrast, "a Napster user who downloads a copy of a song to her hard drive may make that song available to millions of other individuals ... facilitat[ing] unauthorized distribution at an exponential rate." ${ }^{\text {174 }}$ In short, the district court concluded that the conduct of Napster users could not be considered fair use because it threatened the incentives created by copyright. ${ }^{715}$

\section{B. UMG Recordings, Inc v MP3.COM, Inc ${ }^{176}$}

UMG Recordings, Inc v MP3.COM, Inc raised the question of fair use under circumstances in which both the person uploading and

167 Id at 913.

168 Id.

169 Michael Fine, Soundscan Study on Napster Use and Loss of Sales at 15 (Soundscan Jun 12, 2000), available online at <http://www.riaa.com/PDF/fine.pdf (visited Dec 23, 2001).

170 See Napster I, 114 F Supp 2d at 915.

171464 US 417 (1984).

172 Id at 456.

173 See Napster I, 114 F Supp 2d at 913 (distinguishing the case from Sony).

174 Id.

175 This conclusion was affirmed by the Ninth Circuit on appeal. $A \& M$ Records, Inc $v$ Nap ster, Inc, 239 F3d 1004, 1014 (9th Cir 2001) ("Napster II").

17692 F Supp 2d 349 (S D NY 2000). 
downloading the music had purchased a commercial copy of the $\mathrm{CD} .{ }^{17}$ The website MP3.com launched a service, "My.MP3," that would allow a subscriber to listen to her personal collection of CDs anywhere she could access the Internet. ${ }^{178}$ To accomplish this, MP3.com purchased tens of thousands of popular CDs and copied them onto its computer servers to replay to My.Mp3 subscribers. ${ }^{179}$ To obtain access to these recordings, a subscriber had to prove that she actually owned the $C D$ version of the recording, either by inserting a copy of the $\mathrm{CD}$ into her computer or by purchasing it from a cooperating online retailer. ${ }^{180}$ The court concluded that on its face, defendant's copying was a presumptive case of copyright infringement. ${ }^{181}$

In its defense, MP3.com argued that its service should be considered fair use because it enabled users to "space shift." In other words, the service simply replicated a user's traditional ability to listen to music she owns in different locations. Instead of having to bring a $\mathrm{CD}$ with her, she could simply listen to it over the Internet. In rejecting the fair use defense, the court, like the court in Napster, concluded that the copying and playing of music was not considered a transformative or productive use, that music recordings were at the core of intended copyright protection, and that whole works were copied. ${ }^{183}$ The pivotal factor, therefore, was market harm.

On the question of market harm, the recording companies could not demonstrate any loss in either $\mathrm{CD}$ sales or the market for digital downloading. Arguably, My.Mp3 enhanced CD sales because both MP3.com and its subscribers had to purchase CDs. ${ }^{1 \text { se }}$ Similarly, MP3.com was not competing with copyright owners in the digital downloading market. It merely provided a service to users who had already purchased a $\mathrm{CD}$ or digital download, arguably enhancing the markets for both. ${ }^{185}$ Nonetheless, the court found these arguments unpersuasive: "Any allegedly positive impact of defendant's activities on plaintiffs' prior market in no way frees defendant to usurp a further market that directly derives from reproduction of plaintiffs' copyrighted works." ${ }^{186}$ In other words, space shifting was another potential

177 Id at 350 .

178 Id.

179 Id.

180 Id.

181 Id.

182 Id at $350-51$.

183 See id at 351-53 (analyzing MP3.com's actions under the fair use doctrine enunciated in 17 USC $\$ 107)$.

184 See id at 352 (rejecting as unpersuasive the argument that the defendant's activities enhanced the plaintiff's sales).

185 See id.

186 Id. 
market for copyright owners, and in the absence of their authorization, MP3.com had no right to enter that market. The fact that My.Mp3 was merely the digital analog to a consumer's current ability to space shift was irrelevant. Wholeheartedly buying the copyright optimist position, the court concluded that a copyright "is not designed to afford consumer protection or convenience but, rather, to protect the copyright holders' property interests." ${ }^{187}$

\section{Universal City Studios, Inc v Reimerdes ${ }^{128}$}

If Napster and MP3.COM stand for the proposition that copyright should "extend rights into every corner where consumers derive value from literary and artistic works," ${ }^{189}$ Universal City Studios, Inc v Reimerdes adds that protecting this expansion is important enough to justify restrictions upon free speech. ${ }^{100}$ The controversy in Reimerdes arose because the motion picture industry uses $\operatorname{CSS}^{191}$ to control access to and prevent the copying of motion pictures recorded on DVDs. ${ }^{192}$ In September 1999, Jon Johansen, a fifteen-year-old, and two others created DeCSS, a program capable of "ripping" DVDs, which then allows users to play the data on noncompliant computers as well as copy the recordings. ${ }^{1.35}$ The defendants, who published the magazine 2600: The Hacker Quarterly, posted DeCSS on their website ${ }^{144}$ and linked to other sites posting DeCSS. ${ }^{105}$

Eight major motion picture studios brought suit under an anticircumvention provision of the $\mathrm{DMCA}^{106}$ to enjoin 2600 from posting DeCSS. ${ }^{197}$ The anticircumvention provisions prohibit offering to the public or trafficking in any technology designed to circumvent a technological measure that controls access to a work. ${ }^{198} 2600$ argued that the posting of DeCSS was speech protected by the First Amendment. $^{\text {1.9 }}$

187 Id.

188111 F Supp 2d 294 (S D NY 2000).

189 Goldstein, Copyright's Highway at 236 (cited in note 9).

190 See Reimerdes, 111 F Supp 2d at 332 (recognizing that computer code is within the area of First Amendment concern, but holding that under the circumstances of the case the application of the DMCA's antitrafficking provisions did not violate the First Amendment).

191 CSS is "an encryption based system that requires the use of appropriately configured hardware such as a DVD player or a computer DVD drive to decrypt, unscramble and play back, but not copy, motion pictures on DVDs." Id at 308.

192 See id.

193 See id at 311 (describing the creation and development of DeCSS).

194 See <http://www.2600.com> (visited Jan 15, 2002).

195 See Reimerdes, 111 F Supp 2d at 312.

19617 USC $\$ 1201$ (a)(2) (Supp 1999).

197 Reimerdes, 111 F Supp $2 d$ at 303.

198 See 17 USC $\$ 1201$ (a)(2).

199 Reimerdes, 111 F Supp 2 d at 304. 
While the court agreed with 2600 that computer code was expressive, ${ }^{20}$ it concluded that the DMCA is a content-neutral regulation that only incidentally affects expression. ${ }^{201}$ As such, the DMCA would be upheld if (1) it furthers an important or substantial governmental interest (2) unrelated to the suppression of free expression and (3) the incidental restriction on free expression is no greater than is essential to further that interest. ${ }^{202}$ For this discussion, only the first part of the three-part test is relevant.

In upholding the anticircumvention provisions, the court concluded that the important governmental interest justifying the DMCA's restrictions upon expression is "the protection of copyrighted works stored in digital media from the vastly expanded risk of piracy in this electronic age. ${ }^{203}$ According to the court:

Once a decryption program like DeCSS is written, it quickly can be sent all over the world. Every recipient is capable not only of decrypting and perfectly copying plaintiffs' copyrighted DVDs, but also of retransmitting perfect copies of DeCSS and thus enabling every recipient to do the same. They likewise are capable of transmitting perfect copies of the decrypted DVD. The process potentially is exponential rather than linear.

Consequently, unless the dissemination of DeCSS is stopped, it is likely to produce "virtually unstoppable infringement of copyright." In the court's view, the spread of DeCSS and the copying it enables resembled an epidemic in which each "infected" individual is capable of spreading the disease, but unlike a disease, none of those "infected" has an interest in being "cured." tion of this outbreak is important enough to justify restricting even the fundamental right of freedom of expression.

D. Conclusion

Napster, MP3.COM, and Reimerdes demonstrate the degree to which the copyright optimists have succeeded in framing the terms of the debate. All three decisions turn upon the perceived importance of copyright and Congress's determination that copyright owners should have the right to exploit any and all markets for copies. These deci-

200 See id at 326 ("It cannot seriously be argued that any form of computer code may be regulated without reference to First Amendment doctrine. The path from idea to human language to source code to object code is a continuum.").

201 Id at 329.

202 Id at 329-30.

203 Id at 330.

204 Id at 331.

205 Id at 332.

206 Id. 
sions demonstrate the limits of relying upon a significant social value to justify exceptions to copyright, especially with respect to consumer copying. In balancing copyright's goals with the public's interest in obtaining music for free, "free music" loses because there is no overriding societal interest in it. As Justice Blackmun noted in Sony, "When the ordinary user decides that the owner's price is too high, and forgoes use of the work, only the individual is the loser., ${ }^{207}$ Not only did the courts in Napster and MP3.COM both agree with Justice Blackmun that there is no significant interest served in consumer copying, in Reimerdes, the court concluded that Congress's interest in prohibiting such copying was substantial enough to justify restricting even freedom of speech. The remainder of this Article provides an alternative criticism of copyright's expansion by demonstrating that copyright's exclusive rights to reproduce and distribute digital works are not only unnecessary to encourage the creation and dissemination of such works, they hamper the progress of science and the useful arts.

\section{The ECONOMICS OF DigITAL Distribution}

In the United States, copyright protection is justified solely as an incentive for the creation and distribution of content. ${ }^{238}$ As discussed above, the protection of music, literary works, and other content is not based upon the moral or natural rights of authors. ${ }^{209}$ Instead, copyright exists to ensure that content will not be underproduced as a result of the public-good characteristics of intellectual property. ${ }^{200}$ The artificial scarcity created by copyright is justified to the extent that the incentives it creates are needed to make works available to the public. This means that if adequate financial incentives or market conditions exist to inspire the creative activity of authors and encourage them to make their works available to the public without copyright, copyright protection should not be recognized. ${ }^{211}$ Over thirty years ago, thenProfessor Breyer argued that books and other copyrighted works may not be entitled to copyright protection because the economics of pub-

207464 US at 477 (Blackmun dissenting).

208 For the purposes of this Article, creation is defined as the act of producing an original work and fixing the work in digital form. Distribution is defined as the act of making and disseminating subsequent copies.

209 See Sony, 464 US at 429.

210 See Part II.

211 See Lunney, 49 Vand $L$ Rev at 487-88 (cited in note 129) (noting that overbroad copyright protection imposes a cost represented by "the lost value society would have associated with alternative investments to which these resources would otherwise have been devoted"); Landes and Posner, $18 \mathrm{~J}$ Legal Stud at 332 (cited in note 101) (recognizing that "beyond some level copyright protection may actually be counterproductive by raising the cost of expression"); Breyer, 84 Harv L Rev at 322 (cited in note 22) (arguing that copyright's protection of books is not justified). 
lishing rendered copyright unnecessary. ${ }^{212}$ Time and advances in technology may well prove Breyer right, though not for the reasons he suggested.

Today, the economics of digital technology renders copyright both unnecessary and inefficient. In general, discussions about the optimal level of copyright protection ignore distinctions between the incentives for creation and distribution. ${ }^{213}$ In part, the bundling of these interests was strategic. Distributors found that it was to their political advantage to have their interests treated as inseparable from the interests of creators. ${ }^{214}$ In addition to the rhetorical power of equating the interests of distributors with creators, until now the bundling of interests was acceptable because the cost of producing the vesselsCDs, books, and DVDs-for content, and distributing those vessels, was an essential component of making content available to the public. As a result, both sets of costs had to be considered if the public was to enjoy the products of the human mind. ${ }^{215}$ However, as the following demonstrates, because the Internet and digital technology have revolutionized the ways in which we disseminate information, ${ }^{216}$ it is no longer appropriate to treat these interests as interchangeable. Once they are unbundled, it becomes clear that copyright protection cannot be justified as a means of ensuring distribution and is an impermissibly inefficient means for ensuring creation. This Part discusses the need for copyright as an incentive for distribution, and Part V examines copyright as an incentive for creation.

\section{A. The Distribution Technologies of Gutenberg and the Relevance of Copyright}

Arguably, the need to ensure adequate compensation for distributors is at the heart of the neoclassical economic theory of copy-

212 See Breyer, 84 Harv L Rev at 322 (cited in note 22).

213 See Landes and Posner, $18 \mathrm{~J}$ Legal Stud at 327 (cited in note 101) ("To simplify the analysis, we ignore any distinction between costs incurred by authors and by publishers, and therefore use the term 'author' (or 'creator') to mean both author and publisher."); Breyer, 84 Harv L Rev at 292 (cited in note 22) (focusing primarily on the costs of publishing).

214 As developed in England, the efforts of booksellers to obtain copyright were initially unsuccessful until they tied their interests to the interests of writers. See Bettig, Copyrighting Culture at 15-19 (cited in note 95) (noting that copyright originally developed to serve the interests of printers-authors still had to rely upon patronage); Stewart E. Sterk, Rhetoric and Reality in Copyright Law, 94 Mich L Rev 1197, 1197-98 (1996) (challenging the rhetoric claiming that copyright expansion is in authors' best interests); Goldstein, Copyright's Highway at 41-44 (cited in note 9) (discussing how printers secured copyright protection in England for their own interests); Yen, 51 Ohio St L J at 525-26 (cited in note 92) (same). Consider James Boyle, Shamans, Software \& Spleens 81 (Harvard 1996) (discussing the use of the "romantic author" to justify copyright protection).

215 Landes and Posner, $18 \mathrm{~J}$ Legal Stud at 326-27 (cited in note 101).

216 See Part I. 
right. Unlike content creators, who may have significant nonfinancial motivations for creating content, ${ }^{27}$ content distributors are in the business of distribution and cannot ignore financial considerations. In order to distribute music or books, we assume that initial distributors must at the very least recoup their fixed, copying, and distribution costs if they desire in order to stay in business. ${ }^{219}$ It should not come as a surprise, then, that distributors have influenced copyright law's development from its inception and in some cases obtained rights even before creators. ${ }^{20}$

Traditionally, the most significant barrier to distributing works to the public was the magnitude of the investment needed to become a distributor. ${ }^{21}$ Starting a major record company or publishing business is not cheap. In 1984 , estimates suggested that it cost $\$ 125$ million just to maintain a national record distribution operation. In part, this is due to the fact that unlike the author's costs of creation, which are fixed, distribution costs include not only fixed costs but also costs that increase with the number of copies produced. ${ }^{23}$ Each $C D$ must be

217 See Part V.

218 This is not to say that distributors are not concerned about art for art's sake or for reasons such as fame. Unlike artists, however, businesses must consider financial gain if they want to continue as businesses. See Netanel, 106 Yale L J at 340 (cited in note 135) ("But authors must generally depend on publishers to disseminate their work, and publishers generally require, at the very least, the possibility of recovering their costs in selecting, editing, marketing, and distributing creative works.")

219 See Landes and Posner, $18 \mathrm{~J}$ Legal Stud at 327 (cited in note 101) ("For a new work to be created, the expected return-typically, and we shall assume exclusively, from the sales of copies-must exceed the expected cost.").

220 Bettig, Copyrighting Culture at 15-19 (cited in note 95) (noting that copyright initially developed to protect printers, not authors); Goldstein, Copyright's Highway at 40-44 (cited in note 9) (discussing how printers were responsible for the development of copyright law in England); Breyer, 84 Harv $L$ Rev at 292 (cited in note 22) (noting that the first grants of exclusive rights in the fifteenth and sixteenth centuries were made to printers, not authors: "Historically the publisher led the fight for laws that allow him to obtain exclusive rights.").

221 See Eric W. Rothenbuhler and John M. Streck, The Economics of the Music Industry, in Alison Alexander, James Owers, and Rod Carveth, eds, Media Economics: Theory and Practice 199, 213-15 (L. Erlbaum Associates 2d ed 1998) (discussing barriers to entry in the recorded music industry); Statement of FTC Chairman Robert Pitofsky, et al, Five Consent Agreements Concerning the Market for Prerecorded Music in the United States I 21, FTC File No 971-0070 (Aug 30, 2000), available online at $\langle\mathrm{http}: / / \mathrm{www} . \mathrm{ftc} . \mathrm{gov} / \mathrm{os} / 2000 / 09 /$ musicstatement.htm $\rangle$ (visited Dec 21,2001 ) (recognizing that the "wholesale market for prerecorded music is characterized by high entry barriers which limit the likelihood of effective new entry"). See also Miami Herald Publishing Co v Tomillo, 418 US 241, 251 (1974) (recognizing that the expense of becoming a publisher has made entry into the print media "almost impossible").

222 FTC v Warner Communications, Inc, 742 F2d 1156, 1164 (9th Cir 1984). By one estimate, the manufacturing and distribution costs for 110,000 copies of a single CD in Germany in 1998 were approximately $\$ 480,000$. Music Economy Basic Information Service, Calculations for a Pop Album, available online at <http://mebis.com/HitCalc.htm> (visited Dec 21, 2001). This figure excludes marketing and royalties. Overall variable costs, including marketing and promotions, royalties, manufacturing, and distribution, were estimated at $\$ 1,330,000$ for the same album. Id.

223 Landes and Posner, $18 \mathrm{~J}$ Legal Stud at 327 (cited in note 101). 
manufactured, printed, packaged, and distributed. This requires an investment in material, equipment, personnel, and facilities. Moreover, greater demand for, or wider distribution of, a CD means higher overall costs, both for making additional copies and for expanding the distribution network. ${ }^{2 a}$ So in order to make content available to large portions of the population, distributors must have vast resources in terms of capital and infrastructure. Economic incentive theorists, therefore, justify copyright protection as necessary to encourage a distributor to make these significant investments. ${ }^{25}$ If a subsequent competitor could sell copies of the same work without incurring the same expenses as the first distributor, competition would force prices down to the copier's cost, and the initial distributor would not be adequately compensated. ${ }^{226}$ Under those circumstances, potential initial distributors could be deterred from distributing content at all, or would have an increased incentive to distribute "faddish, ephemeral, and otherwise transitory works because the gain from being the first in the market for such works would be likely to exceed the losses from absence of copyright protection. ${ }^{, 27}$ In either case, the public's interest in greater diversity and availability of content would not be served.

Moreover, according to Professor Landes and Judge Posner, as the costs of copying decrease, copyright protection must be increased. According to their economic model, "if, over time, growth in income and technological advances enlarge the size of the market for any given work, and the cost of copying declines, copyright protection should expand."2s While this claim is by no means unassailable, ${ }^{29}$ it appears quite reasonable. As the costs of copying decrease and more individuals are able to afford the technology necessary to copy, one can assume that there will be a greater number of potential copiers. So even though the copying costs for initial distributors will decrease as well, they will be forced to compete with a greater number of copiers and copies. Similarly, as technology reduces the amount of time needed to make copies, any value the initial distributor is able to capture by being first to market will diminish as well. ${ }^{200}$ The need for

224 See Breyer, 84 Harv L Rev at 294-95, 297 n 68 (cited in note 22) (reporting fixed and variable costs for book publishing); Music Economy Basic Information Service, Calculations for a Pop Album (cited in note 222) (estimating costs associated with making a successful CD).

225 Landes and Posner, $18 \mathrm{~J}$ Legal Stud at 335 (cited in note 101) ("Some copyright protection is necessary to generate the incentives to incur the costs of creating easily copied works").

226 Id at 326; Breyer, 84 Harv L Rev at 282 (cited in note 22).

227 Landes and Posner, $18 \mathrm{~J}$ Legal Stud at 332 (cited in note 101).

228 Id at 344.

229 See Breyer, 84 Harv L Rev at 281 (cited in note 22) (arguing against stronger copyright laws).

230 This is an important response to Breyer's argument because one of the advantages an initial publisher would have is lead time. See Breyer, 84 Harv L Rev at 300 (cited in note 22). However, Breyer also suggested that publishers had other strategies, including fighting editions 
greater protection remains even if the copies are made for private use rather than for profit. From the perspective of the initial distributor's incentives, it is the lost revenue attributable to substitute copies that matters-not whether the copier makes a profit.

Content distributors point to the technological developments of the last several decades as proof of Professor Landes's and Judge Posner's claim. Audiotape recorders, videotape recorders, and photocopying machines have reduced the costs of reproducing music, video, and print. Today, many families can afford these copying technologies and are capable of making copies of works instead of purchasing those works for themselves and to distribute to others. ${ }^{231}$ As predicted, with the reduction in costs came an increase in the amount of unauthorized copying. At one point, the RIAA estimated that home taping of music cost the industry approximately $\$ 1$ billion a year in sales. Similarly, the Motion Picture Association of America ("MPAA") currently estimates that its members lose approximately $\$ 3$ billion each year to ana$\log$ piracy. ${ }^{233}$

Napster is a perfect illustration of this claim with respect to digital technology. Falling prices for computers, computer memory, and storage, and the growing availability of high-speed Internet connections, have contributed to an explosion in the copying of digitally recorded music. According to the trial court, Napster users were downloading approximately ten thousand files per second, and the service had an estimated seventy-five million users by the end of $2000 ;{ }^{24}$ by some estimates, it was growing by more than 200 percent a month without marketing. ${ }^{235}$ At this rate, assuming that the industry

and prepublication orders. Id at 301-05.

One possible critique of the economic model is that it appears to overstate the importance of copying costs while not clearly considering the fixed costs of distribution. While a publisher's costs increase with each copy made, that investment is not what is truly threatened by competing copies. Those individual costs are quite small, and the risk of loss can be dealt with strategically. Instead, the more important cost consideration is the initial investment in the equipment necessary to make those copies at all. In other words, while a publisher incurs costs in printing an individual book, those costs are not as significant an investment or barrier to becoming a publisher as the initial investment in personnel, real estate, printing presses, trucks, etc. As technology reduces the costs of copying and distribution, it also reduces the initial investment necessary to become a publisher.

231 See Bettig, Copyrighting Culture at 172, 179 (cited in note 95) (describing the proliferation of home audio-taping and videotaping and noting that the VCR has reached "household saturation"); Goldstein, Copyright's Highway at 147, 157 (cited in note 9) (describing the proliferation of the VCR during the litigation over the VCR).

232 Bettig, Copyrighting Culture at 172 (cited in note 95).

233 Valenti, Copyright \& Creativity at II 16 (cited in note 27).

234 See Napster I, 114 F Supp 2d at 902.

235 Reports also indicate that decentralized peer-to-peer networks like Gnutella have similar potential to distribute content to millions of consumers. See generally Mike Yamamoto and John Borland, A Brave New - or Old -World?, CNET News.com (Oct 26,2000), available online at <http://news.cnet.com/news/0-1005-201-3248711-1.html> (visited Dec 21, 2001) (describing the 
could charge $\$ 1$ per download and that users were willing to pay if Napster were not available, Napster use resulted in $\$ 10,000$ in lost revenue per second. ${ }^{236}$

While content distributors are able to demonstrate growth in unauthorized copying and estimate their resulting losses, it has been harder to demonstrate that copying has eliminated their financial incentives to distribute content. Despite the growth in unauthorized copying, profits continue to rise and the number of new works continues to grow. ${ }^{237}$ There are several responses to these facts. First, content distributors suggest that if they were able to capture the revenues lost to unauthorized copying, they would have distributed even more CDs, videos, and books. ${ }^{239}$ Second, continued profitability can be explained because of economies of scale. ${ }^{239}$ This in turn has increased distributors' incentives to consolidate in order to take advantage of greater economies of scale, and the resulting consolidations have led to a reduction in the number of potential offerings. ${ }^{240}$

Perhaps the most important argument made by content distributors is that they continue to remain viable because copies made with non-digital technology are imperfect substitutes for their products. ${ }^{24}$ Cassette tape recordings of CDs do not provide the same acoustical clarity as the original CD recording. Similarly, a photocopy of a book does not have the same clarity as the printed version. According to some, as long as competing copies remained imperfect substitutes, the

potential of peer-to-peer networking).

236 See Testimony of Gene Hoffman, Jr., Founder, President, and CEO, EMusic.com, Inc, before the Senate Committee on the Judiciary $\$ 3$ (July 11, 2000), available online at <http://judiciary.senate.gov/7112000_ghj.htm> (visited Dec 21, 2001) (noting that EMusic sells individual music tracks for $\$ 0.99$ each). See also Prepared Testimony of Naomi Lefkovitz, General Counsel of CDNow, Inc, before the House Committee on Commerce II 4, Federal News Service (Apr 30, 1998) (noting estimates of online music sales by 2002 as between $\$ 1.6$ and $\$ 4$ billion). Of course, this is a rough estimate, as not every Napster user would be willing to pay.

237 See David Bauder, Napster's Effect on Sales Unclear II 11, AP (Aug 20, 2000), available online at <http://www.washingtonpost.com/wp-srv/aponline/20000820/aponline155851_000.htm> (visited Dec 21, 2001); Brad King, Despite 'Piracy,' CD Sales Up 9 3, Wired News (Apr 24, 2000), available online at <http://www.wired.com/news/business/0,1367,35848,00.html $>$ (visited Dec 21, 2001) (citing statistics showing that "the music industry has grown about 8 percent over last year's first quarter"). This has led some to argue that digital music actually encourages the sale of CDs by acting as a form of advertising.

238 See Ehrlich Testimony at $\mathbb{I} 9$ (cited in note 146) (noting that only a small minority of hits fund all of the investment in new music).

239 Bettig, Copyrighting Culture at 99-101 (cited in note 95) (noting how the film industry benefits from economies of scale).

240 See Neil Weinstock Netanel, Market Hierarchy and Copyright in Our System of Free Expression, 53 Vand L Rev 1879, 1882-83 (2000) (noting the concerns raised by concentration of wealth and power in communications and mass media). But see Christopher S. Yoo, Copyright and Democracy: A Cautionary Note, 53 Vand L Rev 1933, 1940 (2000) (noting that under certain circumstances monopoly may in fact lead to greater diversity of content).

241 See National Research Council, Digital Dilemma at 32 (cited in note 2) (noting that copies made with digital technology are identical to the original). 
original content distributor maintained at least some competitive advantage, and had at least some, although diminished, financial incentive to distribute content. However, digital technology threatens to eliminate even those diminished incentives because copies of the original digital work are now identical to the original, eliminating the first distributor's most important competitive advantage. ${ }^{2 / 2}$

Moreover, only the most reductionist interpretation of incentivebased copyright would argue that society should be unconcerned until all financial incentives are eliminated. Arguably, if our goal is the greater distribution of content, we should be concerned by reductions in the revenues of initial distributors because they necessarily diminish the distributors' incentives to distribute. ${ }^{243}$ This is in part what Professor Lunney describes as the incentive-access paradox. ${ }^{24}$ Any reduction in profit necessarily leads to a reduction in incentives: "If we limit a work's protection to ensure its dissemination, we necessarily reduce the incentive" to distribute the work and decrease the chance that the work would have been distributed in the first place. ${ }^{245}$ As Napster learned, it is difficult to dispute that the unauthorized sharing of music results in at least some loss in revenue, which in turn can be seen as reducing the incentives of the recording industry to distribute digital music.

It would appear that the economic arguments for increased copyright protection are difficult to refute short of arguing over whether existing levels of incentives and availability of content are sufficientan argument with no clear answer. ${ }^{277}$ However, the economic arguments for copyright depend upon an important assumption. They assume that without the creation and recognition of some form of property rights for content distributors, the consuming public will not adequately internalize the cost of making that content available to them, and as a result, less content will be made available. Under the Constitution, copyright protection is, after all, instrumental, and does not exist to protect the financial incentives of distributors for their own sake. As the following discussion demonstrates, the economics of digital technology challenges this assumption.

242 See id.

243 See Landes and Posner, $18 \mathrm{~J}$ Legal Stud at 326 (cited in note 101).

244 See Lunney, 49 Vand L Rev at 557 (cited in note 129) (discussing how reducing the rent an author receives reduces the incentive to create).

245 Id.

246 See Prepared Testimony of Tom Silverman, CEO of Tommy Boy Records, before the House Small Business Committee, Federal News Service II 9 (May 24,2000) ("Every lost sale is a lost royalty.").

247 See Bell, 76 NC L Rev at 557 (cited in note 78). See generally Breyer, 84 Harv L Rev 281 (cited in note 22) (arguing that some publishers should have sufficient incentives to publish without copyright). 


\section{B. Digital Distribution and the Irrelevance of Copyright}

The Internet and digital technology clearly threaten copyright as we know it, but are they a threat because they prevent copyright from accomplishing its purpose? Or is the real threat of Internet file sharing its potential to eliminate the need for copyright and content distributors? If the threat is the former, then efforts to expand copyright protection and prohibit the activities of Napster and similar services are consistent with Congress's power to promote the progress of science and the useful arts. However, if the nature of the digital dilemma is that copyright is no longer needed as a vehicle for distributing content to the public, then copyright's expansion is inconsistent with the promotion of progress. Instead of viewing Internet file sharing as a threat, we should consider the possibility that it is the solution to the distribution problem created by free riding and the public good nature of information.

While copying content for public distribution in the brick-andmortar world of paper, plastic, trucks, and warehouses requires a significant investment, in cyberspace, copying and distribution costs are virtually nonexistent. ${ }^{248}$ As discussed earlier, the fixed costs are less than $\$ 1,000 .{ }^{249}$ Once a work is created, the marginal cost of making an unlimited number of digital copies and distributing them worldwide is zero. ${ }^{250}$ Low costs, combined with the ease of distributing and finding content through Napster and other online technologies, mean that content is capable of spreading over the Internet like an unstoppable viral outbreak, ${ }^{251}$ or, to borrow a phrase from Thomas Jefferson, a "fire, expandable over all space..252 After all, the Internet is a file-sharing platform, ${ }^{233}$ and in 2000 over half the adult population (104 million adults) and almost three-quarters of children ages twelve to seventeen in the United States had access to the Internet. ${ }^{24}$ That is the power of digital technology and the reason content distributors fear the Inter-

248 See Part I.

249 See Part II.

250 See Valenti Warns of the Dangers of Internet Piracy before Congressional Subcommittee at II 9, MPAA press release (Oct 28, 1999), available online at <http://www.mpaa.org/jack/99/ 99_10_28a.htm> (visited Dec 21, 2001) (recognizing that the Internet allows "a single pirate with a single copy of film to produce thousands of copies in a few hours, which are then distributed to sites all over the world").

251 See Reimerdes, $111 \mathrm{~F}$ Supp $2 \mathrm{~d}$ at 332 (comparing the distribution of unauthorized copies with an epidemic).

252 Letter from Jefferson to McPherson at 1015 (cited in note 1).

253 See Reno v American Civil Liberties Union, 521 US 844, 850 (1997) (discussing the origins of the Internet).

254 Associated Press, The Booming Net Population at II 1-3, Wired News (Feb 18, 2001), available online at <http://www.wired.com/news/print/0,1294,41889,00.html> (visited Dec 21, 2001). 
net. ${ }^{25 s}$ But how does this eliminate the need for financial incentives to distribute information to the public?

The Internet eliminates the need to create financial incentives because it eliminates the free rider problem of information distribution. When content is distributed through the Internet, the public internalizes the costs of distribution. As discussed earlier, copyright accomplished this by providing content distributors with exclusive rights to reproduce and distribute content, which in turn enabled them to pass on the costs of distribution to the consuming public through sales. $^{255}$

In cyberspace, free riding is eliminated because the public internalizes the cost of copying and distribution by purchasing the components necessary to connect to the Internet-a computer, Internet access, storage media, and of course electricity. ${ }^{25}$ The same products and services that make it possible for consumers to access the Internet for e-mail are all that are required to copy and distribute digital content for one person or millions. ${ }^{258}$ They are also relatively inexpensive. ${ }^{259} \mathrm{By}$ paying for these products and services, consumers in effect purchase the components that make the copies and form the distribution channels for disseminating digital content. From the perspective of intellectual property theory, this is revolutionary because content can now be disseminated to consumers without the need for anyone other than consumers to invest in distribution. ${ }^{260}$

255 See Part IV.A; Landes and Posner, $18 \mathrm{~J}$ Legal Stud at 332 (cited in note 101) (arguing that as the market for copying expands, the need for copyright increases).

256 See Part IV.A; Landes and Posner, $18 \mathrm{~J}$ Legal Stud at 327 (cited in note 101) (noting that sales of copies must exceed expected costs).

257 See Part I. See also John Borland and Jim Hu, Napster Model Could Make ISPs Subsidize Record Labels at I 4, CNET News.com (Feb 21, 2001), available online at <http://news.cnet.com/news/0-1005-200-4890649.html> (visited Dec 21,2001) (reporting that use of peer-to-peer services shifts the cost of distributing music to consumers).

258 See Part I. See Information Infrastructure Task Force, White Paper at 12 (cited in note 2) (noting that one individual can be a distributor using the Internet).

259 See Part II. See also MPAA, Valenti Warns of the Dangers of Internet Piracy at II 10 (cited in note 250) (noting that the equipment for distributing digital content is inexpensive and highly portable).

260 An argument could be made that this is not so revolutionary because broadcasting shares similar characteristics with Internet distribution. With broadcasting, consumers internalize the cost of receiving programming by purchasing televisions or radios. However, the technologies differ because of the significant market entry barriers to becoming a broadcaster, including the enormous investment in capital required and the scarcity of broadcast frequencies. See Barry $R$. Litman, The Economics of Television Networks, in Alison Alexander, James Owers, and Rod Carveth, eds, Media Economics: Theory and Practice 131, 132-33 (L. Erlbaum Associates 2d ed 1998) (discussing barriers to entry and spectrum scarcity). The two distribution technologies are also similar because neither depends upon a right to exclude the public from content. In the case of broadcast, the costs of transmission are funded by the public in the form of public subsidies and the sale of advertising time. 
Napster illustrates the Internet's ability to distribute content without the need for copyright. Peer-to-peer platforms such as Napster allow users to share content stored on the hard drives of other users. So if a user digitally records songs from a $\mathrm{CD}$ onto her hard drive to listen to them while writing an article or to download them to a portable player for enjoyment while jogging, once she connects to a peer-to-peer network, millions of other users can now make copies of that music for free. Similarly, if a group like the Dave Matthews Band makes a digital recording of a new song available for downloading on the Internet, ${ }^{261}$ millions of copies of that song can be distributed to consumers through the Internet at no cost to the band. ${ }^{262}$ As the district court in the Napster case recognized, the potential scope of this technology is breathtaking. ${ }^{263}$ If the digital music experience is any example, copyright is no longer needed for distribution. ${ }^{24}$

One potential criticism of this argument is that Napster and other businesses that provide Internet services are simply replacing existing

261 See Phil Gallo, Dave Matthews Makes 'Everyday' Count, Yahoo! News (Mar 17, 2001), available online at <http://dailynews.yahoo.com/htx/nm/20010307/re/music_sales_dc_6.html> (visited April 3,2001) (reporting the band's sales of nearly 750,000 copies of its new album in the first week after distributing a song for free on Napster).

262 Consumers are also not limited to listening to music on their computers, but can transfer those files to CDs with the purchase of CD burners and blank CDs.

263 Reports also indicate that decentralized peer-to-peer networks like Gnutella have similar potential to distribute content to millions of consumers. See Borland, P2P Myth at II 21-25, CNET News.com (cited in note 4).

264 One study, however, has shown that even peer-to-peer networking may not entirely avoid the free rider problem. See Eytan Adar and Bernardo A. Huberman, Free Riding on Gnutella at II 23-25, First Monday (Oct 2000), available online at $<$ http://www.firstmonday.org/issues/issue5_10/adar/index.html> (visited Dec 21, 2001). After studying file sharing through Gnutella, researchers at Xerox found significant free riding, with approximately 25 percent of Gnutella users providing 98 percent of the content available, and 1 percent of the users providing 37 percent of the content. Id at $\mathbb{I} 25$. According to this study, this free riding results in a "tragedy of the digital commons," because when only a few users provide content, the performance of the entire system is slowed due to bandwidth constraints. Id at 3941. While this is clearly an important concern, it does not undermine my thesis for two reasons. First, while free riding may slow the speed of a peer-to-peer network, it does not prevent content from being distributed-it just affects the speed at which it is distributed. As consumer access to higher bandwidth continues, technology should minimize if not eliminate the worldwide wait. Second, peer-to-peer networks like Gnutella are not the only or even the most efficient way for consumers to share files. Content can just as easily be distributed through web pages, newsgroups, online communities, clubs, chat rooms, and e-mail. Moreover, content can be distributed more efficiently through centralized services such as those provided by websites, Internet service providers, and hybrid peer-to-peer networks like Napster that do not suffer from the same bandwidth constraints. Once maintaining control over copyright is no longer a concern, artists themselves will likely make works available in order to obtain related financial rewards. As such, this problem is largely an artifact of the current copyright regime. Gnutella and similar services are currently considered important alternative means for distribution primarily because it is more difficult to enforce copyright law against decentralized systems. If I am correct, and copyright protection is no longer justified with respect to digital content permitting other avenues of digital distribution, the free rider problem associated with peer-to-peer networks should become a minor concern. 
content distributors like the members of the RIAA or the MPAA. ${ }^{265}$ If so, why should Napster or AOL profit from distributing content, rather than the members of the recording or motion picture industry? If Napster and Internet service providers ("ISPs") were in the business of selling copies of songs to the public, this criticism would be valid, and arguably allowing Napster to compete with the RIAA would be unfair even if Napster distributes music more efficiently. ${ }^{266}$ However, to the extent that this claim is based upon some theory of contributory or vicarious liability, it is groundless. ${ }^{267}$ While Napster may profit from providing a service that facilitates private copying, like the photocopying machine and the VCR before it, as long as the underlying conduct of the public is permissible, Napster cannot be subject to legal sanction. ${ }^{268}$ To the extent that the argument against Napster or an ISP is based upon a theory of unfair competition or misappropriation, ${ }^{259}$ the argument is circular. Holding Napster responsible under either theory requires the conclusion that Napster has appropriated something of value that rightfully belongs to content distributors, which is precisely the subject of this inquiry. So while there may be some truth to the claim that Napster and AOL would be replacing content distributors, the criticism currently has no policy significance and should have no legal significance. ${ }^{270}$

Of course, the content distribution industry recognizes the Internet's ability to shift costs to consumers, and would like to use it for its own benefit. ${ }^{2 n}$ For example, the recording industry clearly intends to

265 See Hardy, 1996 U Chi Legal F at 220 (cited in note 104) (noting that online services sell access to information).

$266 \mathrm{My}$ argument is solely on behalf of noncommercial copying. Even in the absence of copyright protection, unauthorized commercial copying could be dealt with under principles of unfair competition. See International News Service v Associated Press, 248 US 215, 235 (1918) (recognizing a claim for unfair competition even in the absence of a property right in news).

267 See Napster $I, 114$ F Supp 2d at 918-22 (analyzing Napster's liability for contributory and vicarious infringement); $A$ \& M Records, Inc v Napster, Inc, 239 F3d 1004, 1019-24 (9th Cir 2001) (“Napster II") (same). See also Alfred C. Yen, Internet Service Provider Liability for Subscriber Copyright Infringement, Enterprise Liability, and the First Amendment, 88 Georgetown L $\mathrm{J} 1833,1848$ (2000) (discussing potential theories of enterprise liability for ISPs, including contributory and vicarious infringement).

265 See Sony, 464 US at 491 (Blackmun dissenting) ("[I]f a significant part of the product's use is noninfringing, the manufacturers and sellers cannot be liable for the product's infringing uses.").

269 See International News Service, 248 US at 236 (noting that "unfair competition in business must be determined with particular reference to the character and the circumstances of the business").

270 Admittedly, there is a fine line between copying and providing a service that facilitates copying. However, to the extent that we believe that creators of music are entitled to a portion of the revenues earned by a file-sharing service like Napster, that compensation can be provided without creating exclusive rights in reproduction and distribution. See Part VI.B.

271 See Borland and Hu, Napster Model Could Make ISPs Subsidize Record Labels at II 20, CNET News.com (cited in note 257) (reporting that BMG executives were "cleatly delighted" by 
enter the digital music market once it eliminates the threat of free file sharing. ${ }^{2 n}$ If successful, its profitability will be phenomenal. By distributing music digitally, the recording industry will eliminate all the costs associated with making copies and distributing music physically. It will no longer need raw materials, factories, warehouses, stores, or the personnel that go with them. As Bertelsmann E-Commerce Group President Andreas Schmidt stated when the Group announced its partnership with Napster, "If we do this, we will have almost no additional costs but have additional revenues coming in.... [A]11 these delivery costs, all these distribution costs, go away." ${ }^{213}$ Instead, consumers will purchase the computers, Internet connections, and storage media that are the distribution channels of cyberspace.

Moreover, in addition to the revenues the music industry will receive from the public directly in the form of licensing fees for the privilege of downloading music (or in the extreme case the revenue from charging for each time a song is played), it will receive revenue indirectly from the public with the sale of each blank $\mathrm{CD}$, tape, digital recording device, and computer, even if it plays no role in manufacturing or distributing those products. ${ }^{274}$ The only real expenses it will incur will be the costs associated with protecting its intellectual property in the distribution process. ${ }^{225}$ In the language of economics, the recording industry will be able to externalize the cost of distributing music while reaping monopoly profits from every market associated with music. In the language of Dire Straits, "that ain't working, that's the way you do it, get your money for nothing ...",216

In light of the distributive power of the Internet, the economics of digital content distribution bears no relation to the economics of the brick-and-mortar world. The structure and economics of cyberspace

this cost shifting).

272 See Brian Bergstein, RealNetworks, Record Labels Form Subscription Service at 4 , AP (Apr 2, 2001), available online at $<\mathrm{http}: /$ www.suntimes.com/output/tech/02mus.html $>$ (visited Jan 15, 2002) (reporting a deal between AOL Time Warner, Bertelsmann AG, and EMI Group with RealNetworks to distribute music on a subscription basis); Ehrlich Testimony at 19 16-22 (cited in note 146) (discussing the recording industry's intent to enter the digital downloading market). See also Napster $I, 114 \mathrm{~F}$ Supp $2 \mathrm{~d}$ at 908 (noting that the record company plaintiffs were preparing to enter the digital download market).

273 Borland and Hu, Napster Model Could Make ISPs Subsidize Record Labels at II 22, CNET News.com (cited in note 257).

274 See Audio Home Recording Act of 1992, Pub L No 102-563, 106 Stat 4237, codified at 17 USC $\S \S 1001-10$ (1994) (imposing a royalty payment system on importers, manufacturers, and distributors of digital audio recording equipment). See also Edmund L. Andrews, Fighting Free Music, Europeans Take Aim at Personal Computers, NY Times A1 (Feb 13, 2001) (describing how European music producers are seeking to impose a tax on computer equipment).

275 See Part VI. One could argue that distributors also incur the costs of marketing. However, for the purposes of this discussion, marketing is treated as a cost of creation.

276 Dire Straits, Money for Nothing (lyrics), available online at $<$ http://www.letssingit.com/lyrics/d/dire-straits/6.html > (visited Dec 21, 2001). 
promise to end the free rider problem and the market failure associated with distributing content using the technologies of Gutenberg and the industrial revolution. Instead, digital technology provides the promise of a world in which content, once created, flows freely around the world in a stream of electrons. This is made possible by the fact that consumers bear the costs of distribution themselves, eliminating the need for third-party investments in distribution. Accordingly, the artificial scarcity and exclusive rights created by copyright are not needed to encourage distribution. When the rights of distributors are unbundled from the rights of creators, the case for protecting the rights of distributors cannot be supported. Under these circumstances, copyright serves no purpose other than to transfer wealth from the public and, as we shall see, artists to distributors. In this case, the use of Napster is not theft-copyright is theft.

\section{COPYRIGHT AND THE CREATION OF MUSIC}

As the foregoing discussion demonstrates, the economics of digital technology requires us to separate the incentives for creating and disseminating content to the public. Once they are unbundled, the justification for copyright as a means for encouraging distribution disappears, because private goods are no longer needed to disseminate the public good. We are now able to focus on the more fundamental question of whether copyright is justified as a means of encouraging creation. Assuming, as some have, that in the absence of copyright, all existing content will eventually migrate onto the Internet, ${ }^{2 \pi}$ society should be concerned with the question of whether new content will be created. While a CD or book may be a private good that is no longer necessary, music and poetry still suffer from the problems associated with being a public good. The following discussion examines the role and efficacy of copyright in the creation of music. Because the costs associated with creation vary depending upon the kind of work, copyright may well play a different role with respect to music than it does with motion pictures or other works. ${ }^{278}$ With regard to music, the exclusive rights created by copyright cannot be justified as a necessary, or even the most efficient, means of encouraging creation.

\section{A. The Costs of Creating Music}

In a digital world, the costs of creation should become the only costs in making content available to the public, and talent the only

277 Mann, The Heavenly Jukebox, Atlantic Monthly at 53 (cited in note 23).

278 See Breyer, 84 Harv L Rev at 351 (cited in note 22) ("One must know facts about a particular industry before one can accurately weigh the various costs and benefits associated with copyright protection."). 
barrier to entry. Unlike brick-and-mortar distribution costs, creation costs are fixed one-time investments and in general relatively small. Once a musician records a song, an author types out a manuscript, or a filmmaker tapes footage, there are no additional costs associated with creation no matter how many times the content is copied or how far across the globe it is disseminated. Moreover, while the time and emotional commitment may be significant, the financial investment is relatively small in comparison to that required for global distribution, the creation of motion pictures being the principal exception. ${ }^{279}$ By one estimate, the typical major-label artist spends $\$ 100,000$ to $\$ 200,000$ on studios, musicians, and other production costs to record an album.

Advances in technology have reduced the costs of creation as well. Today, a home computer capable of word processing, editing video, and recording, sampling, and mixing music can be purchased for under $\$ 900 .^{281}$ Recording and editing software and hardware can be purchased for approximately $\$ 150 .^{25}$ These elements combined enable a musician to record music at home with almost the same acoustical quality as music recorded in a professional studio. ${ }^{23}$ Similarly, a competitive professional home recording studio can be built for approximately $\$ 30,000$, giving artists even greater flexibility to record their own music. ${ }^{24}$ Accordingly, recouping the fixed costs of recording music may not be as much a concern as the opportunity costs associated with pursuing a career as an artist rather than as a doctor or an investment banker.

\section{B. The Irrelevance of Copyright}

Unbundling the incentives for the creation and dissemination of music exposes the myth that copyright plays much of a role in encouraging the creation of music. The relative importance of copyright to creators and distributors is most evident when one considers the fact that even with copyright protection, the vast majority of musical artists do not earn any income in the form of royalties from the sale of

279 According to the MPAA, the average major studio film in 1999 cost $\$ 52$ million to produce. See Valenti, Copyright \& Creativity at 2 (cited in note 27 ).

280 Jon Healey, Breaking Down the Cost of Compact Discs at $\mathbb{1}$ 13, SiliconValley.com (Sept 2, 2000), available online at <http://www0.mercurycenter.com/svtech/news/indepth/docs/ cd09032000.htm > (visited Dec 26, 2001).

281 See, for example, Office Depot's technology catalog, available online at <http://www.techdepot.com> (visited Dec 21, 2001).

282 Eric A. Taub, Homemade Music with a Professional Sound, NY Times G11 (Dec 21, 2000 ) (describing several products that can be purchased for under $\$ 150$ ).

283 Id.

284 Bruce Burger, Musicians Find There's No Place Like Home at I1 10, Elec Engineering Times (July 5, 2000), available online at <http://www.eetimes.com/story/OEG20000705S0048> (visited Dec 21,2001). 
music. ${ }^{235}$ In fact, not only do musicians rarely earn royalties from the sale of CDs, they are often in debt to the recording industry for the costs of manufacturing, marketing, and distributing their music. ${ }^{265} \mathrm{Re}-$ cording companies typically charge the artist for all the costs of production, marketing, promotion, and other expenses, including breakage - a holdover from when albums were made from vinyl. ${ }^{257}$ Even in today's digital world, in which the cost of digital distribution is nonexistent, some record labels have demanded that artists surrender even larger portions of their royalties for the cost of encoding the song to digital format, encryption, and digital delivery. ${ }^{238}$ As one report indicates, an artist must typically sell a million copies of a CD before she receives any royalties because record companies deduct the costs of production, marketing, promotion, and other expenses from the musician's royalties. ${ }^{239}$ Meanwhile, the same million copies will have earned the record company approximately $\$ 11$ million in gross revenue and $\$ 4$ million net. ${ }^{230}$ The income to most artists from performance and mechanical rights for songwriting and composing from the sale of music are similarly insignificant. ${ }^{212}$

For example, Roger McGuinn, a songwriter and musician formerly with the Byrds, testified before the U.S. Senate regarding his thirty years of experience as a musician. ${ }^{22}$ According to McGuinn, who has recorded over twenty-five albums in his career, "I cannot support my family on record royalties alone. ${ }^{, 233}$ For the more than fifteen albums he recorded with the Byrds, in most cases all he received was a modest advance from Columbia Records. ${ }^{294}$ Even a top forty hit during his solo career did not provide him with any income from album

285 Healey, Breaking Down the Cost of Compact Discs at $\mathbb{I} 16$, SiliconValley.com (cited in note 280 ) (reporting that "the average recording artist never sees any royalties"); Mann, The Heavenly Jukebox, Atlantic Monthly at 50 (cited in note 23).

286 Mann, The Heavenly Jukebox, Atlantic Monthly at 50-51 (cited in note 23).

287 Healey, Breaking Down the Cost of Compact Discs at $\mathbb{1} 14$, SiliconValley.com (cited in note 280).

288 Id (reporting that "some executives at the major labels contend that those costs are higher than the ones they replace").

289 Mann, The Heavenly Jukebox, Atlantic Monthly at 50 (cited in note 23). See also Courtney Love, Courtney Love Does the Math, Salon.com (June 14, 2000), available online at $<$ http://www.salon.com/tech/feature/2000/06/14/love/print.html> (visited Dec 21, 2001) (discussing the costs and revenue associated with a record deal, and how a band that obtains a milliondollar advance and sells one million copies of an album could earn nothing); David Segal, Aspiring Rock Stars Find Major-Label Deals-and Debts, Wash Post A1 (May 13, 1995) (discussing how even successful musicians end up in debt to major record labels).

290 Mann, The Heavenly Jukebox, Atlantic Monthly at 50 (cited in note 23).

291 Id.

292 Statement of Roger McGuinn, songwriter/musician, before the Senate Committee on the Judiciary (July 11, 2000), available online at <http://judiciary.senate.gov/7112000_rm.htm $\rangle$ (visited Nov 20,2001).

293 Id at II 6.

294 Id at $\mathbb{I} 2$. 
sales. ${ }^{295}$ Similarly, when he sold approximately five hundred thousand copies of an album for Arista in 1989, and in 1996 for Hollywood Records, he received no royalties from album sales. ${ }^{226}$ Instead, McGuinn makes his living through live performances, with the publicity from the recordings creating an audience for his live performances. ${ }^{207}$

And McGuinn is one of the lucky few musicians who can make a living as an artist. Given that the average album release is under twenty-five thousand per $\mathrm{CD},{ }^{298}$ few musicians are lucky enough to have a top-forty hit or sell almost half a million albums. According to the RIAA's own statistics, between 1992 and 1999, less than 1 percent of audio releases sold a million or more copies. ${ }^{299}$ So while a few elite artists make money from the sale of music, the vast majority of artists do not. It should, therefore, be no surprise that with respect to the private sharing of digital content, the artists are divided. ${ }^{300}$ In light of the current state of affairs, free, noncommercial distribution of music should have little or no impact on the incentives for creating music.

If, as the economic theory of copyright assumes, individuals require a financial incentive to create, where do artists find this incentive, if not from copyright ? $^{301}$ First of all, it is highly unlikely that aspiring artists think in terms of copyright at all. To the degree that they are inspired by the financial rewards of becoming a successful artist, they are dreaming of financial rewards in general, and those financial rewards remain even without copyright's exclusive rights to reproduce and distribute music. As the following demonstrates, musicians can and do earn significant income by means other than selling copies of their works.

For most musicians like McGuinn, live performances are the principal source of income..$^{3 / 2}$ As John Perry Barlow, a lyricist for the

295 Id at $\mathbb{1 I} 4$

296 Id at $1915-6$.

297 Id at II 6.

298 Healey, Breaking Down the Cost of Compact Discs at II 15, SiliconValley.com (cited in note 280) (citing industry estimates).

299 This calculation is based upon an RIAA report that between 1992 and 1999, the recording industry released 241,400 audio recordings, including new and rereleases. See RIAA Market Data, New Release Figures, available online at <http://www.riaa.com/md-us-6.cfm> (visited Dec 21,2001). During that same time period, RIAA certified 1,867 records as platinum (that is, selling at least one million copies).

300 See Napster, Artists Sound Off, available online at <http://www.napster.com/speakout/ artists.html> (quoting artists); RIAA Artists, New Media Issues, Music Online: The Future Is Now, available online at <http://www.riaa.org/Arists-Issues-1.cfm> (visited Dec 21, 2001) (same).

301 Admittedly, some artists may find an incentive in the hope that they too may one day become one of the few who make money through copyright. See Mike Stoller, Songs That Won't Be Written, NY Times A15 (Oct 7, 2000) ("I fear for the 17-year-old songwriter looking forward to a career in the music business today.").

302 See Barlow, The Economy of Ideas at $* 8$, Wired (cited in note 45) (describing how the Grateful Dead relied upon live performances, and not copyright, to fund themselves); McGuinn 
Grateful Dead and cyber-commentator, notes, the live experience that only the actual band can provide has significant commercial value. ${ }^{303}$ This experience can also be quite lucrative. For example, in March 2001, the Backstreet Boys sold $\$ 1,952,674$ in tickets for two shows in Los Angeles, and Matchbox 20 sold \$552,275 in tickets for one night in New York. ${ }^{34}$ Elton John sold $\$ 772,636$ in tickets for one night in December $2000 .^{305}$ In 2000 alone, concerts in North America generated over $\$ 1$ billion in revenue. ${ }^{306}$ For the artist, free music is a complementary good that increases ticket sales. ${ }^{307}$ According to Barlow, the Grateful Dead "have been letting people tape our concerts since the early seventies, but instead of reducing the demand for our product, we are now the largest concert draw in America, a fact that is at least in part attributable to the popularity generated by those tapes." ${ }^{309}$ As a result, some artists see Napster and file sharing as a way of introducing their music to new fans in order to promote concert sales. ${ }^{300}$

Indeed, artists do not limit themselves to exploiting the market for live performances. Eliminating the exclusive right to reproduce and distribute music digitally does not mean that all other rights should be eliminated as well. Artists should still retain the rights to license derivative works and trademarks, and to endorse products and services. ${ }^{310}$ As a result, popular artists will still be able to earn significant income from the licensing and sales of tie-in products such as Harry Potter dolls, Star Wars figures, and concert T-shirts. They will continue to receive revenue from endorsements, advertising, and public appearances. Likewise, artists should be entitled to licensing revenue from all commercial uses of their works, including broadcasting. Allowing the public to copy music and other works for personal use does not mean that others should be free to exploit an artist's work for profit. As George Lucas demonstrated to the motion picture in-

Testimony at II 6 (cited in note 292); Testimony of Peter Breinholt, recording artist, before Senate Committee on the Judiciary II 8-11 (Oct 9, 2000), available online at <http://judiciary.senate.gov/1092000_pb.htm> (visited Dec 21, 2000).

303 Barlow, The Economy of Ideas at *8, Wired (cited in note 45).

304 See <http://www.billboard.com/charts/boxscore.asp> (visited Apr 3, 2001).

305 Id.

306 Ray Waddell, Tour Business Should Profit from Big Summer Lineup, 113 Billboard 1 (Mar 17, 2001).

307 See Barlow, The Economy of Ideas at *8, Wired (cited in note 45); McGuinn Testimony at II 6 (cited in note 292); Breinholt Testimony at III 8, 10 (cited in note 302). Economists define a complementary good as a product whose fall in "price will cause the quantity demanded for the other product to rise." Richard A. Posner, Economic Analysis of Law 49 (Aspen 5 th ed 1998).

303 Barlow, The Economy of Ideas at *8, Wired (cited in note 45).

309 Breinholt Testimony at II 9 (cited in note 302).

310 See generally Jeffrey Brabec and Todd Brabec, Music, Money, and Success (Schirmer 2d ed 2000) (discussing the available sources of income to artists). See also Donald S. Passman, All You Need to Know about the Music Business (Simon \& Schuster 2000) (same). 
dustry, for the artist, these secondary markets can be more lucrative than the right to reproduce and distribute content. ${ }^{311}$

In addition to these traditional sources of income, the Internet may facilitate new methods of obtaining income by connecting artists directly to their audiences. Recently, Stephen King experimented with what can be described as the ransom model of self-publishing. ${ }^{312}$ King requested that individuals who download installments of his latest story pay him $\$ 1$ per installment (subsequent installments were priced at $\$ 2$ ), but he did not demand or require payment up front. ${ }^{313}$ Instead, he announced that if he did not receive payments for at least 75 percent of downloads, he would not finish the story. ${ }^{34}$ To date, as reported by King's website, he has completed the first book with plans for a second, and made over $\$ 400,000$ in profit. ${ }^{315}$ What this means for musicians is that they could tease the public with free samples but withhold releasing a full album, refuse to release any new works, or refuse to go on tour until sufficient compensation has been received. As it did for King, the frictionless environment of the Internet should make it easier for artists to reach their fans to make their pleas or threats. ${ }^{316}$

A close cousin to the ransom approach is tipping. For example, Espra and Snarfizilla are file-sharing services like Gnutella or Freenet, but when users download a specific song, they are given the opportunity to tip the artist whose work they are downloading. ${ }^{317}$ Despite the limits of charitable giving and the existence of alternative services that neither require nor facilitate "tipping," artists are already receiving income from this service. ${ }^{318}$ While the current income revenue is not significant (reportedly, artists such as David Bowie and U2 have received checks that "are usually less than a hundred" dollars), tipping might become a source of significant income as these networks expand. First, Internet tipping functions clearly facilitate voluntary giving by reducing the transaction costs associated with connecting the public to a particular artist and by reminding the public of the artist's financial needs. Additionally, the significance of tipping will most likely grow in direct relationship to the size of the sharing network. The low level of

311 See generally Howard Maxford, George Lucas Companion (Batsford 1999); Dale Pollock, Skywalking: The Life and Films of George Lucas (Samuel French Trade 1990).

312 David D. Kirkpatrick, Stephen King Sows Dread in Publishers with His Latest E-Tale, NY Times C1 (July 24, 2000).

313 Id.

314 Id.

315 See <http://www.stephenking.com> (visited Dec 21, 2001).

316 See Cohen, 97 Mich L Rev at 561 (cited in note 119) (describing how the Internet can help reduce transaction costs).

317 David Kushner, Tipping for Tunes at II 1, RollingStone.com (Mar 7, 2001), available online at $<\mathrm{http}: / / \mathrm{www}$. rollingstone.com/news/newsarticle.asp?nid=13427> (visited Dec 21, 2001). 318 Id. 
tipping illustrated by Snarfizilla may be explained in part by the size of its user base. In contrast, even if only 1 percent of Napster's registered users tipped for each download, those tips would amount to half a million dollars in revenue per song. Depending upon the availability of a tipping function, voluntary giving could represent a significant source of revenue for artists. ${ }^{319}$

The foregoing demonstrates that currently copyright plays a minimal role, if any, in encouraging the creation of music. The vast majority of artists do not earn their income from the sale and distribution of music. Rather, they earn their income from the fame and publicity that go with the distribution of music. Ticket sales, T-shirt sales, and commercial endorsements are all a function of an artist's popularity. By facilitating the distribution of music, Napster and the Internet in general can be useful tools for increasing an artist's ability to earn revenue as a result of fame. This is especially beneficial to new or nonmainstream artists who are otherwise unable to capture the public's attention through more traditional media. ${ }^{320}$ Given the low transaction costs associated with the Internet, digital technology also allows for creative solutions such as ransoming and tipping to increase revenue to artists without the need for denying the public access to their works. While some artists may earn more under the current copyright regime from the sale of physical copies of their works than they would absent copyright, the evidence that artists require those revenues as incentives to make music is scant at best.

When one recognizes that the Internet and digital technology eliminate the need for distributors and weaken their stranglehold on the public, reduce the costs of creation, and reduce the transaction costs associated with connecting artists to the public, most artists may in fact be far better off in a world without copyright. Nonetheless, if one believes that the revenue sources other than the sale of physical albums create insufficient incentives, a claim that appears to lack any empirical proof, there is an alternative to copyright.

\section{THE Digital RECORdING ACT}

Almost forty years ago, Kenneth Arrow argued that, under economic principles, the public's interest in encouraging the creation and

319 Legislation could be enacted to require file-sharing services to include a tipping function. While this may raise a First Amendment objection with respect to compelled speech, it may, nonetheless, survive constitutional scrutiny because it is justified by a substantial, if not compelling, governmental purpose in protecting the incentives for creation, and is narrowly tailored to achieve that purpose.

320 See Amy Harmon, Unknown Musicians Find Payoffs Online, NY Times A1 (July 20, 2000) (reporting on how Internet exposure benefits unknown artists). 
dissemination of content is best served through government subsidy. Public funds could be used to fund creation without denying anyone access to the work. ${ }^{32}$ In response, Harold Demsetz challenged the idea that public funding is necessarily superior to a market regime. ${ }^{323}$ According to Professor Demsetz, a market-based property regime provides important information regarding consumer preferences that allows artists to channel their investments accordingly. ${ }^{324}$ In other words, without sales, investments in creation would be made inefficiently. Concerns over public funding can also be seen in Neil Netanel's more recent evaluation of copyright from the perspective of democratic self-governance. In addition to signaling consumer preferences, "copyright fosters the development of an independent sector for the creation and dissemination of original expression, a sector composed of creators and publishers who earn financial support for their activities by reaching paying audiences rather than depending on state or elite largess.",325 The degree to which the public's preferences may be manipulated by government subsidy or corporate sponsorship is an important concern given copyright's democracy-enhancing role. ${ }^{36}$ So while a private property regime denies access to those who cannot or will not pay, a public regime makes it difficult to determine what the public wants and threatens the independence of artists. Once again, the Internet and digital technology may address both sets of concerns.

\section{A. The Proposal}

To the extent that additional financial incentives for the creation of music are considered necessary, Congress could enact a Digital Recording Act ("DRA"). This Act could fund artists through a scheme similar to the one enacted by the Audio Home Recording Act of 1992 ("AHRA"). ${ }^{327}$ Congress passed the AHRA in response to industry concerns that digital audiotapes would undermine the market for $\mathrm{CDs}^{328}$ Among other things, the AHRA imposes a 3 percent statutory

321 Kenneth Arrow, Economic Welfare and the Allocation of Resources for Invention, in National Bureau for Economic Research and the Committee on Economic Growth of the Social Science Research Council, The Rate and Direction of Inventive Activity, Economic and Social Factors: A Conference of the Universities 609, 623 (Princeton 1962).

322 Id.

323 See Harold Demsetz, Information and Efficiency: Another Viewpoint, 12 J L \& Econ 1 (1969).

324 Id.

325 Netanel, 106 Yale L J at 347 (cited in note 135).

326 Id.

327 Pub L No 102-563, 106 Stat 4237, codified at 17 USC $\$ 1001-10$ (1994).

328 See HR Rep No 102-873(II), 102d Cong, 2d Sess 2 (1992) ("The music recording industry became concerned that the DAT recorder's 'perfect' copying capabilities could significantly decrease consumer demand for commercially prerecorded music products because there would be significantly more illegal 'perfect' copies in circulation."). 
levy on the sales of blank digital audiotapes and a 2 percent levy on the sale of digital audiotape equipment. ${ }^{329}$ These funds are then divided pursuant to a formula among the recording industry, performers, publishers, and writers. ${ }^{30}$

Using a similar model, the DRA could easily provide a source of revenue for musicians and songwriters instead of copyright. Statutory levies could be imposed on subscriptions for Internet service and the sales of computer, audio, and video equipment. ${ }^{331}$ Germany is considering imposing a flat fee on all the components of home computers that can be used in copying (CD burners, hard drives, scanners, and printers). ${ }^{332}$ While this fee would increase the cost of a fully equipped computer by $\$ 80$, it is estimated that the fee would raise $\$ 500$ million a year in Germany alone. ${ }^{333}$ According to the U.S. Census Bureau, in 2000 , U.S. computer and software stores made approximately $\$ 23$ billion in sales, and radio, television, and electronic stores earned approximately $\$ 42$ billion. ${ }^{334}$ A 2 percent levy on these sales would yield approximately $\$ 1.3$ billion for distribution to artists per year. This represents the projected revenues for the entire digital downloading market under copyright in 2002 , or roughly $\$ 48,000$ per new release.

Furthermore, unlike traditional government subsidy of the arts, the funds generated under the DRA would not have to be divided equally or selected by government officials, but could be disbursed based upon the popularity of works. ${ }^{335}$ As Senator Orrin Hatch recognized, it is possible to monitor and track the downloading and use of digital works on the Internet. ${ }^{337}$ Web pages and computer networks can

329 See 17 USC \$ 1004.

330 Id $\S 1006(\mathrm{~b})$.

331 Not only do these services contribute to the copying and dissemination of digital music, they arguably benefit from its popularity. Free music could be considered a complementary good for these products and services because it increases their sales.

332 Edmund L. Andrews, Fighting Free Music, Europeans Take Aim at Personal Computers, NY Times A1 (Feb 13, 2001).

333 Id. From the public's perspective, a one-time payment of $\$ 80$ at every upgrade of a computer is much more affordable than even a modest subscription payment of $\$ 10$ per month.

334 See US Census Bureau, Monthly Retail Trade Survey (2000), available online at $<\mathrm{http}: / /$ www.census.gov/mrts/www/data/html/sal00.html $>$ (visited Dec 21, 2001). These figures are used purely for illustrative purposes, as they are both overinclusive (because they contain the sales figures for noncomputer equipment) and underinclusive (because they do not contain the figures for computer sales through other stores or online).

335 See Recording Industry Association of America, The Cost of a $C D$ at II 7, available online at <http://www.riaa.org/md-us-7.cfm> (visited Dec 21, 2001) (estimating that roughly twenty-seven thousand new releases hit the market per year).

336 Similar proposals were put forward to deal with home video recording that would have imposed fees on VCRs and blank tapes and distributed the revenues based upon audience ratings. See Bettig, Copyrighting Culture at 167-69 (cited in note 95) (discussing proposals).

337 See Prepared Testimony of Senator Orrin G. Hatch before the Senate Committee on the Judiciary II 10 (July 11, 2000), available online at <http://judiciary.senate.gov/ judiciary/ 7112000_ogh.htm> (visited Dec 21,2001) ("Both Emusic and MP3.com can track usage levels to 
be programmed to track user behavior, recording whether a user downloaded any files and the identity of the files accessed, and can even be programmed to suggest files that a user might like to access based upon prior behavior. ${ }^{338}$ Files can also be individually programmed to "phone home" each time they are used. ${ }^{339}$ Through this technology it is possible for artists to evaluate consumer preferences, and therefore direct their investments, without the need for a private property regime.

For example, Billboard.com maintains listings of the top downloads at various websites. ${ }^{3+0}$ Napster, AOL, and other networks could build similar tracking systems of their own. By tracking what music is being listened to, the funds from the statutory levy could be disbursed based upon consumer preference, whether defined by the percentage of downloads, number of downloads, percentage of use, or any number of formulas. When combined with the power of e-mail, chat rooms, bulletin boards, and websites to connect artists to their fans, digital technology promises not only to replace sales as an indicator of consumer preferences, but also to paint a more accurate picture while providing artists with more income than they currently receive under copyright. At the same time, no one would be denied access to the artists' works.

Moreover, in contrast to a pay-per-use regime in which each individual's use must be monitored, determining consumer preferences for the purposes of disbursing funds to artists requires only monitoring of aggregate use. The identity of specific individuals is not necessary for artists to determine whether the public enjoys their works. Accordingly, such a system should alleviate the privacy concerns raised by the monitoring and tracking (of what specific individuals

accurately account to the artists for use of their music and pay them accordingly.").

338 See Brad King, Emusic Tracks Napster Naughties at $\mathbb{1}$ 1, Wired (Nov 21, 2000), available online at <http://www.wired.com/news/business/0,1367,40316,00.html> (visited Dec 21, 2001) (reporting that engineers had developed a system to track and identify infringing material on the Napster network). See also Information Infrastructure Task Force, White Paper at 183-94 (cited in note 2) (discussing copyright protection technologies). Compare Samuelson, The Copyright Grab at $\mathbb{I} 19-48$, Wired (cited in note 10) (discussing non-technology and technology copyright protection solutions).

339 See Samuelson, The Copyright Grab at II 28 (cited in note 10) (discussing smart technologies that would allow copyright owners to monitor public copying and use); Chris Oakes, Word Docs with Ears at III 2-4, Wired News (Aug 31, 2000), available online at $<$ http://www.wired.com/news/technology/1,1282,38516,00.html> (visited Dec 21,2001) (reporting that it is possible to place code in a word processed document or e-mail message that tracks subsequent use of the file by allowing the document to "phone home").

340 See <http://www.billboard.com/billboard/hotweb/index.jsp> (visited Dec 21, 2001) (listing the most popular music downloads at various websites). See also Hepler, Comment, 37 San Diego L Rev at $1176 \mathrm{n} 53$ (cited in note 57) (noting that Rolling Stone magazine listed the "Top 10 Pirated Internet Tracks"). 
read, listen to, and watch) that would be required in order to implement the "celestial jukebox.","

\section{B. Copyright Rejoinders}

Assuming that the DRA and other sources of revenue provide sufficient incentives for creation, several important questions remain. First, what about marketing costs? While these alternative sources may be sufficient for artists to recoup their costs of recording music and may provide sufficient incentives to become an artist in the first place, they may not cover the high costs of marketing. Second, wouldn't the continued recognition of copyright still benefit the public because it would provide even more incentives for creation? Lastly, while this argument may be accurate in an entirely online world, we currently have a dual system of distribution. Is copyright necessary to protect offline distribution?

\section{Marketing.}

By one estimate, a major recording label spends roughly $\$ 140,000$ to $\$ 350,000$ per album in marketing, promotion, and tour support. ${ }^{3.2}$ Given the high cost of marketing, one could argue that, in the absence of copyright, it may be difficult, if not impossible, for an artist to recoup the costs of both creating and marketing a work. There are several responses to this concern.

First, eliminating the right to control reproduction and dissemination of music does not eliminate a musician's ability to market her work. Obviously, to the extent that artists desire marketing, they can invest accordingly, and the Internet will help. For example, Napster is in fact a very powerful marketing tool. One artist described peer-topeer technology as a "high-tech version" of word of mouth. ${ }^{343}$ Similarly, websites like MP3.com can help promote an artist at significantly lower cost than traditional media marketing. ${ }^{344}$ The rise of Internet radio should also help artists reach new fans by increasing the number of global "stations" tailored to specific consumer tastes."

341 See Cohen, 28 Conn L Rev at 1003-30 (cited in note 15) (arguing that the First Amendment guarantees a right to read anonymously).

342 Healey, Industry Seeks to Justify Huge Overhead on the Price of Compact Discs at 3 (cited in note 280).

343 Breinholt Testimony at II 9 (cited in note 302).

344 Id.

345 See World Beat, Research Shows Web Radio Can Succeed:21 Stations Attract Respectable Numbers at II 4, Nyrock.com (Apr 5, 2001), available online at <http://www.nyrock.com/worldbeat/04_2001/040501.asp> (visited Dec 21, 2001) (reporting that Internet radio allows programmers to aggregate geographically splintered listening audiences who prefer similar genres); Associated Press, Bowie Sees Velvet Goldmine in Net Radio at II 2, CNET News.com (Apr 4, 2001) (reporting that musician David Bowie will launch his own Inter- 
Recently, the rock band Smashing Pumpkins demonstrated the power of the Internet to distribute music without traditional marketing when they released their final album. ${ }^{346}$ With the exception of twenty-five vinyl copies of the album, the twenty-five song album was released for free exclusively in MP3 format. ${ }^{3.7}$ The Drudge Report and MTV originally reported the release, and the news then spread through message boards on the Smashing Pumpkins website and fan sites. $^{343}$ Once released, the songs spread across the Internet, with unaffiliated websites "hosting" the songs and people sharing them over Napster and other services.

Second, in many respects the argument that copyright should be used to subsidize marketing is the exact opposite of the consumer preference argument and should be rejected for the same reasons that the consumer preference argument must be addressed. While marketing admittedly provides consumers with important information such as the availability of a new album or artist, ${ }^{30}$ it allows wealth to distort, rather than reflect, the market. ${ }^{351}$ Under these circumstances, copyright as a means for recouping marketing costs is inconsistent with the economic and democratic justifications for copyright. To the degree that this means that the ability of major recording labels and already suc-

net radio service), available online at <http://news.bbc.co.uk/hi/english/entertainment/musid newsid1260000/1260747.stm> (visited Dec 21,2001); Eve Epstein, Online Radio Hits Its Stride at II 5, CNN.com (May 23, 2000), available online at <http://www.cnn.com/2000/TECH /computing/05/23/web.radio.idg/index.html> (visited Dec 21, 2001) (reporting how online radio, which is estimated to yield advertising revenues of $\$ 12$ billion to $\$ 22$ billion by 2005 , allows users to tailor their own content).

346 Cecily Barnes, The Smashing Pumpkins Take Music Directly to Napster Fans, CNET News.com (Sept 12, 2000), available online at <http://news.cnet.com/news/0-1005-2002761354.html > (visited Dec 21, 2001).

347 Id.

$348 \mathrm{Id}$

349 Id.

350 Lillian R. BeVier, Competitor Suits for False Advertising under Section 43(a) of the Lanham Act: A Puzzle in the Law of Deception, 78 Va L Rev 1, 8 (1992) ("Advertising contributes to consumer welfare by providing information.").

351 As it is currently structured, the major recording companies routinely manipulate what the public hears by paying radio stations to play their music. See Douglas Abell, Pay-for-Play, 2 Vand J Enter L \& Prac 52, 52 (2000) (discussing how the recording industry compensates broadcasting stations for playing their songs); Mann, The Heavenly Jukebox, Atlantic Monthly at 53 (cited in note 23) (noting that five companies control approximately 85 percent of the market for recorded music in the United States, in part because of their marketing muscle). See also Terence A. Shimp and Ivan L. Preston, Deceptive and Non-deceptive Consequences of Evaluative Advertising, $45 \mathrm{~J}$ Marketing 22, 22 (Winter 1981) (suggesting that advertising can distort the consumer's information processing); BeVier, 78 Va L Rev at 4-5 (cited in note 350) ("Economistcritics of advertising claim that it impedes competition in three ways. First, they claim that advertising creates barriers-to-entry; second, that advertising distorts tastes; and third, that advertising manipulates demand."); John Kenneth Galbraith, The New Industrial State 281-82 (Houghton Mifflin 4th ed 1985) (arguing that advertising manipulates demand). But see BeVier, 78 Va L Rev at 4-8 (cited in note 350 ) (arguing that advertising is economically efficient). 
cessful artists to promote works will be limited because consumers prefer other works, so be it. Copyright exists to protect creation, not to increase any individual creator's chances of being accepted in the marketplace. ${ }^{352}$ The government's ability to restrict the marketdistorting effects of money may be limited, ${ }^{353}$ but the government should not recognize property rights for the sole purpose of creating or amplifying those distortions.

\section{Exclusive rights maximize incentives.}

As the preceding demonstrates, the financial incentives created by copyright are no longer needed for the creation of works and their dissemination to the public. The Internet and digital technology not only make it possible for the public to internalize the costs of distribution, but they may also help level the playing field for artists by reducing the market distortions created by compensation schemes based predominantly upon the sale of hard copies. Nonetheless, while copyright may not be necessary, can it still be useful? In other words, will it do any harm to continue to recognize copyright? The continued recognition of copyright's exclusive rights is not only unnecessary, but also detrimental to society. As Professor Stewart Sterk reminds us, "Copyright protection has serious costs.",35s

Initially, the pessimist critiques of copyright's expansion are now even more compelling, because the countervailing interests in content creation and distribution no longer exist. In a pre-digital world, while one may have justified restricting access to works even for scholarly or expressive purposes because copyright protection could be viewed as an equal engine for free expression, ${ }^{366}$ that argument is no longer accurate. There are no substantial, let alone compelling, governmental interests to justify restricting public access to works when access is sought for important or compelling purposes. Consequently, the district court's conclusion in Reimerdes that the DMCA's restrictions

352 See Litman, 39 Emory L J at 969 (cited in note 94) ("Nurturing authorship is not necessarily the same thing as nurturing authors."). Similar sentiments are found in antitrust law, which protects "competition, not competitors," Brown Shoe Co v United States, 370 US 294, 320 (1962), and in Dormant Commerce Clause jurisprudence, which "protects the interstate market, not particular interstate firms," Exxon Corp v Maryland, 437 US 117, 127 (1978).

353 See Virginia State Board of Pharmacy v Virginia Citizens Consumer Council, 425 US 748, 759-61 (1976) (recognizing commercial speech as protected First Amendment expression); Buckley $v$ Valeo, 424 US 1, 143 (1976) (striking down limitations on campaign expenditures). See also Netanel, 53 Vand L Rev at 1928 (cited in note 240) (arguing that copyright fosters speech hierarchy and should include a reinvigorated fair use doctrine).

354 In the past, this may have been justified because distribution costs were high, but as previously discussed, that justification no longer exists. See Part IV.

355 Sterk, 94 Mich L Rev at 1209 (cited in note 214).

356 Harper \& Row Publishers, Inc v Nation Enterprises, 471 US 539, 558 (1985) ("The Framers intended copyright itself to be the engine of free expression."). 
upon expression are justified by the need to protect "copyrighted works stored in digital media" ${ }^{\text {,35 }}$ is simply wrong.

Moreover, the continued recognition of copyright is subject to internal criticism under the very same economic theory used to justify its expansion. In a world in which the public internalizes the cost of distribution and funds creation, and no one is denied access to music, copyright unnecessarily distorts the market for music. Economists recognize that copyright protection involves a tradeoff between providing incentives for creation and access to the work. ${ }^{38}$ Even under circumstances in which copyright is considered desirable, economists have recognized that the optimal level of protection must "be set below the level that maximizes the number of works created." ${ }^{359}$ Otherwise, the marginal value of creating additional incentives by expanding copyright protection is outweighed by the higher costs of expression for works that would have been created without the additional protection and the resulting "greater administrative and enforcement costs." ${ }^{360}$ These resulting costs are objectionable because: (1) the monopoly power created by copyright unnecessarily restricts access to a work, and (2) it potentially strips resources from other areas of the economy.

As noted by Professor Fisher, "Granting an artist or inventor a property right in his creation may make him a monopolist, giving rise to familiar economic distortions. ${ }^{161}$ First, granting copyright holders exclusive rights to content insulates them from price competition because competing works are imperfect substitutes. ${ }^{362}$ This allows the copyright holder to reap monopoly profits for a work by charging a price substantially higher than her marginal costs. ${ }^{33}$ As a result, some consumers who would otherwise have valued the work at more than its marginal cost but are unable or unwilling to pay the monopolistic price will not purchase the work, resulting in a "deadweight loss" to

357 Reimerdes, $111 \mathrm{~F}$ Supp 2d at 330.

358 See Lunney, 49 Vand $L$ Rev at 485 (cited in note 129) (discussing the incentive-access tradeoff); Landes and Posner, $18 \mathrm{~J}$ Legal Stud at 326 (cited in note 101) ("Copyright protection ... trades off the costs of limiting access to a work against the benefits of providing incentives to create the work in the first place.").

359 Landes and Posner, $18 \mathrm{~J}$ Legal Stud at 343 (cited in note 101). See also Sterk, 94 Mich L Rev at 1209 (cited in note 214) ("Indeed, from an efficiency standpoint, the optimal copyright system would not seek to maximize the number of works created but, in recognition of the costs of copyright, would withdraw protection even when marginally more protection would result in a marginal increase in creative activity.").

360 See Landes and Posner, $18 \mathrm{~J}$ Legal Stud at 343 (cited in note 101).

361 Fisher, 101 Harv L Rev at 1700 (cited in note 95).

362 See Lunney, 49 Vand L Rev at 497 (cited in note 129); Fisher, 101 Harv L Rev at 1700-02 (cited in note 95 ).

363 Lunney, 49 Vand L Rev at 497 (cited in note 129). 
society. ${ }^{344}$ This problem is exacerbated by the economics of digital technology. Given that the costs of creation and distribution are already borne by the public without the need for a property right, any price a copyright holder demands for a digital work represents monopoly profits. Even if the price is exceptionally low, some members of the public will be denied access because they are unwilling to pay. This in turn may reduce future creation. . $^{35}$

This monopoly power also results in a transfer of wealth from the consumer to the copyright holder. As a result of the copyright holder's ability to reap monopoly profits, money that would have otherwise remained in the pockets of the consumer will now go into the pocket of the copyright holder. ${ }^{366}$ While some do not view this wealth transfer as a significant concern, ${ }^{37}$ it can be considered problematic under economic theory for several reasons. ${ }^{3 * 3}$ First, the wealth transfer may lead the monopolist to expend more resources politically to maintain the monopoly. From society's viewpoint, these resources are largely wasted, the same way that theft encourages "an expenditure of resources on thieving and on preventing theft." ${ }^{330}$ In the language of public choice theory, as Robert Merges and Glenn Reynolds recognize, "political parasites are a double danger: they not only pursue their own self-interested agenda, but also force others into a political 'arms race' to protect their own interests.... And, of course, efforts aimed at political redistribution of wealth make society poorer, not richer.",311

In addition to the potential political arms race, copy protection for digital content necessitates an expensive technological arms race as well. Given the difficulty of protecting digital works from copying, copyright holders will be forced constantly to spend significant resources developing technology just to keep the cat in the bag. ${ }^{3 n}$ These costs will in turn be passed on to the public, not to provide the public with access to new works, but for the sole purpose of limiting access.

364 Fisher, 101 Harv L Rev at 1702 (cited in note 95). See also Lunney, 49 Vand L Rev at 497-98 (cited in note 129).

365 See Landes and Posner, $18 \mathrm{~J}$ Legal Stud at 343 (cited in note 101). See also Lunney, 49 Vand L Rev at 495-97 (cited in note 129).

366 Lunney, 49 Vand L Rev at 497 (cited in note 129); Fisher, 101 Harv L Rev at 1701-02 (cited in note 95).

367 See, for example, Posner, Economic Analysis of Law at 302 (cited in note 307) (considering "the transfer of wealth from consumers to producers brought about by increasing the price from the competitive to the monopoly level ... as a wash").

368 Outside economics, this may be criticized as an unjustifiable transfer of wealthspecifically, as a taking, class legislation, or capture.

369 Posner, Economic Analysis of Law at 304 (cited in note 307).

$370 \mathrm{Id}$.

371 Merges and Reynolds, 37 Harv J on Legis at 55 (cited in note 151).

372 See Ehrlich Testimony at II 16 (cited in note 146) (discussing how encryption and other technological measures are now important costs in distributing music). 
Given that hackers appear to be as adept, if not more so, at picking the locks of copyright protection as those trying to lock up digital works, the costs associated with a copy protection arms race would be unending. ${ }^{373}$

Similarly, copyright holders would be forced to spend significant resources prosecuting acts of infringement and those persons who assist in those acts. The RIAA's scorched-earth policy with respect to digital technology is a clear example of the enforcement costs associated with maintaining and administering a copyright regime in the digital age. These costs will only increase as Gnutella and other decentralized peer-to-peer networks rise to replace centralized services like Napster, or the services move outside the United States. Under these circumstances, copyright would not exist because of its instrumental value in encouraging creation, but solely to protect copyright holders.

The monopoly power created by copyright may also reduce the copyright holder's incentives to innovate. ${ }^{374}$ Because the monopolist has already "appropriated much of the consumer surplus," what does she have to gain from innovating, and what does she have to lose from not innovating? ${ }^{375}$ In other words, if a musician writes a wildly successful song, and copyright's exclusive rights allow her to earn monopoly profits, it may no longer be important for her to write new songs.

Finally, by making investments in music more desirable than other investments, copyright protection will divert funds and investments from other uses of society's resources. ${ }^{376}$ As Professor Lunney notes:

[T] he potential for lost access is not the only cost broadening copyright entails. If we broaden copyright, we increase the economic return on any given authorship investment. We can thereby lure resources, in the form of labor and capital, away from other productive endeavors into the production of copyrighted works and lead the market to produce additional works. But to create these additional works, we must strip the resources from other sectors of the economy.

In light of these concerns, Professor Lunney argues that copyright should not be used to provide artists with the full value associated with their works. ${ }^{378}$ If copyright were to guarantee individuals the full

373 See also Hardy, 1996 U Chi Legal F at 251 (cited in note 104) (noting the wastefulness of technological arms races).

374 Posner, Economic Analysis of Law at 304 (cited in note 307).

375 Id.

376 Lunney, 49 Vand L Rev at 655 (cited in note 129).

377 Id at 487-88.

378 Id at 654 . 
value of their works, it would discourage investments in every other sector of the economy because in those sectors, individuals generally recover the cost of creating a new product and not the full value. ${ }^{379}$ In other words, copyright should place the financial incentives to become a musician on a level playing field with other careers; it should not create asymmetrical incentives. ${ }^{300}$

In the past, these costs were considered inevitable byproducts of a system designed to promote the creation and dissemination of works and were considered acceptable at certain levels. Given that the Internet and digital technology make it possible for the public to fund the creation and dissemination of digital works without any loss in the ability of the market to determine consumer preferences, the costs of continuing to recognize copyright are simply not worth any increase in incentives. ${ }^{331}$ As the British historian Thomas Macaulay argued, "Copyright is monopoly, and produces all the effects which the general voice of mankind attributes to monopoly.... [T] he effect of monopoly generally is to make articles scarce, to make them dear, and to make them bad." As such, it "ought not to last a day longer than is necessary for the purpose of securing the good. ${ }^{333}$ Accordingly, in the digital era, copyright's exclusive rights to reproduce and distribute works are no longer necessary to secure the public good, and may in fact be inconsistent with the public good.

\section{Copyright is necessary in a dual distribution system.}

Another potential criticism of my argument is that while it may be appropriate for a world in which all works are distributed online, we currently live in a world in which distribution occurs both online and offline. Under this dual distribution system, copyright protection may be considered necessary for both in order to protect the incentives for offline distribution. To the extent that this criticism assumes that offline distribution serves important societal interests, such as providing access to creative works to people who might not have or are unable to afford computer equipment, it merits consideration. It

379 Id. See also Breyer, 84 Harv L Rev at 285-86 (cited in note 22):

[F]ew workers receive salaries that approach the total value of what they produce.... Indeed, when a worker without competition-perhaps because he is the only doctor in the area ...-could charge a price close to the total value of his services to the buyer, we normally encourage competition, which will force him to charge less.

380 See Lunney, 49 Vand L Rev at 654 (cited in note 129).

381 If the revenues provided from other avenues are insufficient to sustain creation, Congress could either enact the DRA or increase the rate.

382 Thomas Babington Macaulay, First Speech on Copyright, in Edwin L. Miller, ed, Macaulay's Speeches on Copyright, and Lincoln's Address at Cooper Union 17, 22 (Houghton Mifflin 1913).

383 Id at 23. 
suggests that we must seriously examine whether such interests exist. For example, in order to preserve the benefits of free television programming, Congress imposed certain restrictions upon cable operators. ${ }^{334}$ However, in upholding these restrictions, the Supreme Court required Congress to demonstrate that the threat to free television programming was real. ${ }^{3.5}$

Otherwise, if the argument is that copyright is necessary because some people may simply prefer offline distribution, this preference is not threatened by my proposal. My argument is technology-neutral. Because commercial copying is still prohibited, distributors of CDs should still have sufficient incentives to distribute CDs as long as the public demands them. The choice to migrate toward online music is left to the public. In the absence of some specific societal need, imposing a regime of exclusive copying and reproduction rights on online distribution is an argument for preserving the monopoly of offline distribution by fiat without any corresponding public benefit.

\section{CONCLUSION}

Throughout history, technology has expanded humanity's ability to communicate, to improve ourselves through art and knowledge, and to pass on what we have learned. Unfortunately, we have not always understood how to respond to technology's advances. Copyright's origins as a tool for censorship and monopoly for the writers' guilds in response to the invention of the printing press should be a cautionary tale as we attempt to promote the progress of science and the useful arts in a digital world. To the extent that this endeavor is fraught with dangers, as Ithiel de Sola Pool observed, "the danger is not of an electronic nightmare, but of human error. It is not computers but policy that threatens freedom." ${ }^{386}$ With respect to today's digital copyright debate, our error is in entering the debate with the familiar assumptions of the old world rather than attempting to understand the new.

Copyright developed as a response to the economics of Gutenberg's printing press, under which works of literature, music, and multimedia are delivered in the form of books, CDs, and videos. In the absence of legal protections against copying, this method for distribution was particularly susceptible to free riding by subsequent copiers. In contrast, today's technology allows us to distribute those same works as ".docs," ".mp3s," and ".mpgs" at virtually no cost. Freed from the

384 See Turner Broadcasting System, Inc v FCC, 512 US 622, 623-34 (1994) (noting the restrictions placed on cable providers to preserve the benefits of free broadcasting).

385 Id at 664-65 (concluding that "Congress must demonstrate that the recited harms are real, not merely conjectural," and that "the economic health of local broadcasting is in genuine jeopardy and in need of the protections afforded by must-carry").

386 Pool, Technologies of Freedom at 226 (cited in note 88). 
economics of the industrial revolution, and connected by the web of the Internet, the technologies of the information revolution eliminate the potential for free riding because, to the extent that there are costs associated with distribution, the public internalizes them. These same technologies also make it possible to fund creation without denying anyone access to works. As this Article demonstrates, the new economics of digital technology promises to revolutionize the ways in which we encourage the creation and dissemination of human expression. It promises a world in which no one is excluded from creations of the mind because he is unwilling or unable to pay. At the same time, it has the potential to encourage the growth of an independent and diverse community of artists who are directly connected to the public. It promises all these things without the need or the costs of making expression something that it is not-property.

Examining the controversy over copyright and digital music is only the beginning. The lessons learned from digital music should apply to other creative endeavors. The critical question for these other endeavors, however, is not whether exclusive rights to reproduce or distribute creative works are necessary, but whether some version of the DRA is necessary to support creation. Arguably, the creation of television programming and motion pictures, like music, may not require additional funding, because it is already adequately funded through advertising revenue, programming subscriptions, and box office ticket sales. In contrast, authors and computer programmers may require some form of DRA to provide incentives for creation because they lack such alternate sources of funding. Of course, the exact response to the creative destruction of copyright for these other creative endeavors deserves further attention.

The creative destruction of copyright also raises questions about the constitutionality of efforts to preserve copyright in cyberspace if copyright's underlying justifications no longer exist. I suggest that if technology has changed the economics of information creation and dissemination, the Intellectual Property Clause's primary role in the digital era should be to protect individual liberty by delineating the limits of congressional and state power to restrict access to digital works. $^{377}$ The expansion of copyright's monopoly into the new tech-

387 See Merges and Reynolds, 37 Harv J on Legis at 64 (cited in note 151) (arguing that the Intellectual Property Clause imposes internal limits upon Congress). Compare with the general discussions in Yochai Benkler, Constitutional Bounds of Database Protection: The Role of Judicial Review in the Creation and Definition of Private Rights in Information, 15 Berkeley Tech L J 535 (2000) (arguing that the Intellectual Property Clause limits government's ability to create exclusive rights); Paul J. Heald and Suzanna Sherry, Implied Constitutional Limits on Congressional Power: Construing the Commerce Power in Light of the Intellectual Property Clause, 2000 U IIl L Rev 1119 (same); Theodore H. Davis, Copying in the Shadow of the Constitution: The Rational Limits of Trade Dress Protection, 80 Minn L Rev 595, 640 (1996) (same); David L. Lange, 
nologies of the Internet when its underlying justification no longer exists would hardly be consistent with Congress's power "[t]o promote the Progress of Science and useful Arts." ${ }^{\text {,38 }}$

Other problems must also be addressed. In a world in which noncommercial copying is permitted, what are the limits of commercial copying? How will we define unfair competition in the digital age? Finally, we must address the digital divide. ${ }^{339}$ If the Internet is to be the new medium for distributing content, we must take steps to ensure that everyone is connected regardless of race, nationality, or socioeconomic status.

There will of course be opposition to this vision. Just as Gutenberg's printing press threatened the dominance of scribes, peer-topeer networking and MP3s clearly threaten the recording industry, whose business depends upon manufacturing and distributing old bottles. While we should be concerned about their plight, we must be careful to identify whose interests are being served by copyright's expansion. Keeping in mind that the digital world will be what we want it to be, we must ask ourselves, will we program it for the benefit of a few, or will we program it for the good of all?

The Intellectual Property Clause in Contemporary Trademark Law: An Appreciation of Two Recent Essays and Some Thoughts about Why We Ought to Care, 59 Law \& Contemp Probs 213 (1996) (same); Malla Pollack, Unconstitutional Incontestability: The Intersection of the Intellectual Property and Commerce Clauses of the Constitution: Beyond a Critique of Shakespeare Co. v. Silstar Corp., 18 Seattle U L Rev 259 (1995) (same).

388 US Const Art I, $\$ 8, \mathrm{cl} 8$.

389 See generally National Telecommunications and Information Administration, Falling through the Net: Defining the Digital Divide (US Department of Commerce Nov 1999), available online at <http://www.ntia.doc.gov/ntiahome/digitaldivide/> (visited Dec 21,2001). 